\title{
RUNX family: Oncogenes or tumor suppressors (Review)
}

\author{
BEATRIZ ANDREA OTÁLORA-OTÁLORA ${ }^{1}$, BERTA HENRÍQUEZ ${ }^{2}$, \\ LILIANA LÓPEZ-KLEINE ${ }^{3}$ and ADRIANA ROJAS ${ }^{4}$
}

\author{
${ }^{1}$ Medicine Faculty, National University of Colombia, Bogotá 111321, Colombia; ${ }^{2}$ School of Biochemistry, \\ Medicine and Science Faculty, San Sebastián University, Santiago 7510157, Chile; ${ }^{3}$ Statistics Department, \\ National University of Colombia, Bogotá 111321, Colombia; ${ }^{4}$ Instituto de Genética Humana, \\ Facultad de Medicina, Pontificia Universidad Javeriana, Bogotá 110231, Colombia
}

Received September 17, 2018; Accepted April 11, 2019

DOI: 10.3892/or.2019.7149

\begin{abstract}
Runt-related transcription factor (RUNX) proteins belong to a transcription factors family known as master regulators of important embryonic developmental programs. In the last decade, the whole family has been implicated in the regulation of different oncogenic processes and signaling pathways associated with cancer. Furthermore, a suppressor tumor function has been also reported, suggesting the RUNX family serves key role in all different types of cancer. In this review, the known biological characteristics, specific regulatory abilities and experimental evidence of RUNX proteins will be analyzed to demonstrate their oncogenic potential and tumor suppressor abilities during oncogenic processes, suggesting their importance as biomarkers of cancer. Additionally, the importance of continuing with the molecular studies of RUNX proteins' and its dual functions in cancer will be underlined in order to apply it in the future development of specific diagnostic methods and therapies against different types of cancer.
\end{abstract}

\section{Contents}

1. Introduction

2. RUNX regulatory role

3. RUNX family dual role in cancer

4. Conclusions

\section{Introduction}

Oncogenesis transforms a normal cell into a tumor cell through the acquisition of basic tumor characteristics denoted

Correspondence to: Professor Adriana Rojas, Instituto de Genética Humana, Facultad de Medicina, Pontificia Universidad Javeriana, Carrera 7 \# 40-62 Edificio 32, Bogotá 110231, Colombia

E-mail: rojas-adriana@javeriana.edu.co

Key words: runt-related transcription factor, oncogenes, tumor suppressor, transcription factor, cancer by the hallmarks of cancer, including sustained proliferative signaling, growth suppressor avoidance, cell death resistance, replicative immortality, angiogenesis, invasion and metastasis activation $(1,2)$. Cancer research has focused on the search for genetic biomarkers capable of regulating the acquisition of oncogenic characteristics, but less than half of the reported effects were related to a cancer-specific endpoint (3). However, epigenetic factors have shown their crucial importance in gene expression regulation through posttranslational modifications without altering DNA sequences (4). Additionally, transcription factors have been identified as a group of proteins with the ability to regulate expression by binding to a large number of gene promoters $(5,6)$. Transcription factors have been consistently deregulated in human cancer due to the presence of translocations, deletions, amplifications and point mutations; additionally, they serve as terminal regulators and convergence points of important oncogenic signaling pathways, becoming novel and promising cancer therapy targets $(5,7)$.

Runt-related transcription factor (RUNX) proteins belong to a transcription factor family of embryonic development master regulators that are involved in essential cellular processes, including proliferation, differentiation, cell lineage specification and even apoptosis (8). Mammals have 3 RUNX genes with very dynamic expression patterns, depending on the differentiation and developmental stages, and microenvironmental signals of cancer (9). Functionally, RUNX1 is important for hematopoietic cell differentiation $(10,11)$, $R U N X 2$ is essential for osteogenesis (12-14) and RUNX3 regulates gastric epithelium growth (15). In cancer, $R U N X 1$ has been associated with leukemia (16-18), and solid tumor development on the skin, lung, intestine and breast $(19,20)$, while $R U N X 2$ has been associated with osteosarcoma (21-23), papillary carcinoma, thyroid carcinoma $(24,25)$, and breast and prostate cancer (26-28), and RUNX3 with gastric cancer (29).

$R U N X$ genes have exhibited dual and contradictory functions in cancer since they can behave as oncogenes or tumor suppressor genes $(9,30,31)$. Experimental evidence has revealed a loss of function in two of the three $R U N X$ genes in cancer; the overexpression of RUNX protein can be oncogenic, while transcriptional activation by retroviral insertion in the three genes leads them to behave like tumor suppressors or oncogenes $(9,32)$. For this reason, the RUNX biological 
characteristics, specific regulatory abilities and current experimental evidence that associates the RUNX family with pro- and anti-tumorigenic processes were investigated in the current review.

\section{RUNX regulatory role}

RUNX proteins belong to a family of transcription factors conservedinevolution that regulate proliferation, differentiation and cell growth in different tissues and specific contexts $(33,34)$. $R U N X$ genes can be identified in C. elegans (35). Bilateria organisms only have one $R U N X$ gene with at least two introns, suggesting that the multiple $R U N X$ genes in vertebrates and insects come from independent duplication events within every lineage (36).

RUNX family genomic and protein structure. The human genome has 3 RUNX genes (RUNX1, RUNX2 and RUNX3), which encode an alpha subunit also known as DNA binding factor polyomavirus enhancer-binding protein $2 \alpha \mathrm{A}$ subunit (PEBP2 $\alpha)$ or core-binding factor subunit $\alpha(\mathrm{CBF} \alpha)$ or acute myeloid leukemia (AML) (9). RUNX forms a heterodimeric complex with $\mathrm{CBF} \beta$, which changes its conformation, exposing its DNA binding site (37), and increasing its DNA binding affinity to exert its function as a sequence-specific trans-activator $(38,39)$. $R U N X$ genes have received different names depending on the species and disease where it was identified as follows: RUNX1/AML1/PEBP $2 \alpha B / C B F A 2$, RUNX2/AML3/PEBP2 $\alpha$ A/CBFA1 and RUNX3/AML2/ PEBP $2 \alpha C / C B F A 3(40,41)$.

In humans, RUNX1 is located on chromosome $21, R U N X 2$ on chromosome 6 and $R U N X 3$ on chromosome 1 (40). RUNX genes share a similar genomic structure (42). $R U N X 1$ is the largest gene with nine exons and 12 possible isoforms, $R U N X 2$ has eight exons and 12 possible isoforms and RUNX3 is the smallest with six exons and two isoforms (Fig. 1) $(43,44)$. RUNX proteins have an mean size of $50 \mathrm{kDa}$ RUNX3 is $44 \mathrm{kDa}$, RUNX1 is $50 \mathrm{kDa}$ and RUNX2 is $57 \mathrm{kDa}(42,43,45)$.

The Runt homology domain (RD; exons 2, 3 and 4) mediates DNA binding and the transactivation domain (TAD; exon 6) mediates protein-protein interactions $(46,47)$. The RD has a highly conserved motif of 128 amino acids near the N-terminus, with a homology degree close to $90 \%$, which binds to a TGt/cGGT element present in its target gene promoter $(38,39)$. The RD three dimensional conformation in its DNA-binding state is an S-type immunoglobulin (Ig) domain (48). The Ig domain is involved in molecular recognition and DNA binding of other transcription factors, including cellular tumor antigen p53 (p53), nuclear factor- $\kappa \mathrm{B}(\mathrm{NF}-\kappa \mathrm{B})$, nuclear factor of activated T-cells and signal transducer and activator of transcription (49). RD has only been identified in Bilateria organisms, suggesting that it may be a creation of metazoans (8).

At the C-terminus, there is an inhibitory domain (ID), which negatively regulates protein expression (50). There is also a highly conserved valine-tryptophan-arginineproline-tyrosine (VWRPY) motif for the interaction with the Groucho/transducin-like enhancer protein (TLE) family of corepressors (51). A 40 amino acid sequence acts as a RUNX activated protein target (52-54). There is also a sequence of nine amino acid located following the $\mathrm{RD}$, called the nuclear localization signal (NLS) (55). The proline-tyrosine (PY) sequence has a proline-rich motif important for protein interaction with a WW domain (56). Comparing amino acid sequences from different species revealed highly conserved RD, VWRPY and PY motifs at the C-terminus (57). However, RUNX proteins have less homology in regulatory elements and protein binding sequence regions, which functionally characterize every RUNX protein (42).

RUNX family transcriptional regulation. In mammals, RUNX genes have two promoters that generate the two most important isoforms. The use of the alternative promoter appeared prior to all the duplication events that gave rise to every $R U N X$ gene (36). The distal promoter (P1) transcription encodes the type II isoform and the proximal promoter (P2) encodes the type I isoform (42). The two isoforms have differences in their 5 'untranslated regions (UTRs) and N-termini, which suggest the binding of specific cofactors to repress or activate their target gene's expression (8).

The RUNX1 5'UTR formed from P1 is short (452 bp), has a canonical Kozak sequence and is efficiently translated in vitro from the internal ribosome entry site (IRES) (58). The 5'UTR formed from P2 is very long (1,631 bp) and contains many ATGs that avoid efficient translation (58-60). There is a large CpG island (CGI) that frames P2, and remains demethylated and independent of lineage or developmental phase (61). Isoforms $1 \mathrm{~A}$ and $1 \mathrm{~B}$ are transcribed by $\mathrm{P} 2$ and isoform $1 \mathrm{C}$ by P1 (62). Isoform $1 \mathrm{~A}$ only contains the RD, which codes 250 amino acids with nine unique amino acids at its 3 '-end (62). Isoforms $1 \mathrm{~B}$ and $1 \mathrm{C}$ contain RD and TAD (62), isoform $1 \mathrm{C}$ has 32 distinct amino acids in its $\mathrm{N}$-terminus and is important for hematopoietic stem cell formation, while isoforms $1 \mathrm{~A}$ and $1 \mathrm{~B}$ are expressed during hematopoietic cell differentiation (62). Transcription is regulated by two tissue-specific enhancers (regulatory elements 1 and 2), which allow erythroid and lymphoid protein binding; therefore, RUNXI is highly active in the hematopoietic system (62).

RUNX2P1leads totypeIIisoformexpressioncalledMASNS, while $\mathrm{P} 2$ leads to type I isoform expression called MRIPV (59). The two mRNA isoforms can be translated with cap mediation and an IRES located in the 5'UTRs (63). RUNX2 expression is regulated by epigenetic mechanisms, such as histone covalent modifications (64). In this regard, COMPASS, a histone modifier complex (WD repeat-containing protein 5/histone-lysine $\mathrm{N}$-methyltransferase $2 \mathrm{~A} /$ lysine-specific demethylase $6 \mathrm{~A}$ ), is responsible for $\mathrm{P} 1$ transcriptional activation through a concerted mechanism that mediates the addition of methyl groups in lysine residues of histone $\mathrm{H} 3$ (H3K4Me3 and $\mathrm{H} 3 \mathrm{~K} 27 \mathrm{Me} 3$ ) and the removal of methyl groups in arginine residues of histone $\mathrm{H} 4$ (H4R3Me2) around RUNX2 P1 (64). This process has been described during mesenchymal cell differentiation processes towards osteogenic and myoblastic lineages, mediated by components of the Polycomb complex group, Trithorax/COMPASS and demethylase lysine-specific demethylase 5B (64).

$R U N X 3$ expression is regulated in a tissue-specific manner in all tissues by its control regions in P1 and P2 (43). P1 has binding sites for factors such as DNA-binding protein Ikaros, transcription factor E26 transformation-specific or 


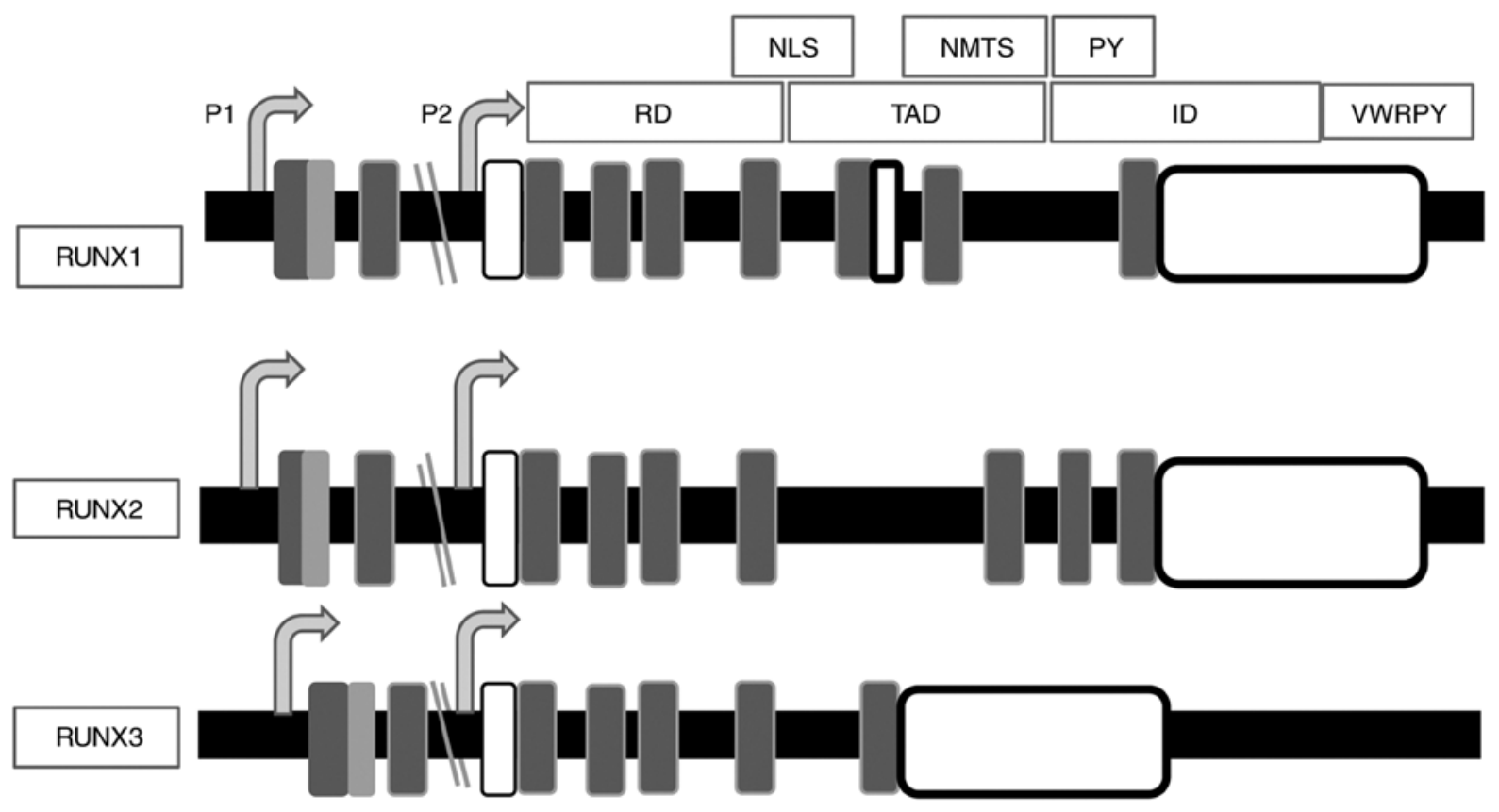

Figure 1. RUNX family genomic and protein structure. The diagram represents the position of several motifs in RUNX family genes. White boxes represent noncoding exons and shaded boxes coding exons. Figure adapted from Fig. 2 in reference (44). RUNX, runt-related transcription factor.

E-twenty-six (Ets), cyclic AMP-responsive element-binding protein 1/cyclic AMP-dependent transcription factor (ATF), while $\mathrm{P} 2$ is rich in GC, contains a CCAAT motif in E-boxes, and contains binding sites for transcription factor $\mathrm{Sp} 1$ and early growth response protein $1(65,66)$. Therefore, RUNX3 P1 and $\mathrm{P} 2$ differ in GC content and transcription factor binding sites (43), suggesting that $R U N X 3$ silencing in normal tissues may be regulated by epigenetic factors. However, only RUNX3 P1 epigenetic regulation in a region outside its CGI has been demonstrated; the CGI was hypermethylated and associated with $R U N X 3$ repression in normal gastric epithelial cells (67).

$R U N X 3$ spatiotemporal expression is regulated by the cross-talk between enhancers and promoters in a tissue-specific manner, as those identified in NT-3 growth factor receptor proprioceptive neurons during dorsal root ganglia development $(68,69)$. The Zinc finger and BTB domain-containing protein $7 \mathrm{~B}$ is a transcription factor that binds to RUNX3 enhancers to negatively control its expression, possibly avoiding loop formation between the enhancers and RUNX3 $\mathrm{P} 1$; this is a process that depends mainly on the T-lineage commitment factor, B-cell lymphoma/leukemia 11B, to couple $\mathrm{T}$ cell receptor signals with the transcriptional program governing thymocyte lineage decisions (70).

$R U N X$ genes are acetylated by histone acetyltransferase p300 (p300), which allows them to modulate their transcriptional activation and to remain functionally stable (71). RUNX levels are controlled by proteasome-mediated degradation, which suggests specific RUNX activity control in response to different stimuli (35). E3 ubiquitin-protein ligase SMURF (SMURF)1 and SMURF2 promote RUNX proteasomal degradation mediated by CBF $\beta$ and paired amphipathic helix protein $\operatorname{Sin} 3$ a (Sin3A), a specific histone H4 methyltransferase that modifies lysine 4 (72,73). RUNX mRNA can support alternative splicing processes that generate additional isoforms (42), with RUNX3 as an exception that does not have isoforms produced by this mechanism (43), as it does not contain RUNX1 and RUNX2 extra exons and stop codons (74).

RUNX complex function is determined by a diverse and highly dynamic range of posttranslational modifications (specifically, methylation, phosphorylation, acetylation and ubiquitination) that affect its gene expression, protein activity, subcellular location and stability (39). The DNA and multiple posttranslational modifications of the RUNX family determine how the activities of the transcription factors regulate cell cycle progression or the response to external stimuli (8).

RUNX proteins are the substrates of several kinases such as serine/threonine-protein kinase pim-1 (Pim-1), mitogenactivated protein kinase (ERK, also known as MAPK) and cyclins-cdk (75). Pim-1 is a proto-oncogene that phosphorylates all RUNX proteins (75). Pim-1 phosphorylates RUNX3 to enhance its stability and cytoplasm location (76). Increased expression of RUNX2 and Pim-1 leads to T-cell lymphoma synergistic development (77). RUNX1 is phosphorylated by the serine/threonine kinase ERK2, increasing its transactivation ability (78), but reducing protein stability due to Sin3A corepressor dissociation (79). Homeodomain-interacting protein kinase 2, a protein kinase, phosphorylates RUNX1 to promote cooperation between RUNX1, histone acetyltransferase KAT6A (MOZ) and p300 to activate transcription $(80,81)$.

RUNX proteins mediate regulation. RUNX proteins are weak transcriptional regulatory factors when acting independently; therefore, they require interaction with other proteins to increase or decrease their activity (9). Additionally, RUNX proteins form functional complexes with other proteins to activate and repress the transcription of key regulators associated with cell growth and differentiation, demonstrating a dual function of this family (39).

The RUNX family recruits' corepressors to repress the transcription of multiple target genes through its VWRPY 
motif interaction with the Groucho/TLE family of corepressor proteins (82). Corepressor $\mathrm{mSin} 3 \mathrm{~A}$ association allows the recruitment of histone deacetylases (HDACs) 1 and 2, for cyclin-dependent kinase inhibitor 1 (p21 $\left.{ }^{\text {Wafl/Cip}}\right)$ expression in NIH3T3 cells, a fibroblast cell line sensitive to the foci formation of leukemia and sarcoma viruses (83). RUNX1 is clearly associated with HDACs 1,3 and 9, and weakly associated with HDACs 2, 5 and 6; RUNX2 recruits HDAC6, whereas RUNX1 and RUNX3 recruit SUV39H1 to suppress transcription (84).

The RUNX family recruits coactivators to activate the transcription of multiple target genes (9). RUNX1 binds to ETS1 through its ID, eliminating its requirement for $\mathrm{CBF} \beta$ and leading to a better DNA binding ability, which encourages transactivation and synergistic promoter activation (85). RUNX1 binds ETS-related transcription factor Elf (NERF)-2 and NERF-1 to activate and repress tyrosine-protein kinase Blk, a B cell-specific gene, respectively (71). RUNX1 and RUNX2 bind to proto-oncogene c-Fos and transcription factor AP-1 through the RD to activate the collagenase- 3 gene promoter (72). TAD acts through the recruitment of histone acetyl transferases, including MOZ and mortality factor 4-like protein, which physically interact with RUNX1 and RUNX2, clearly stimulating transactivation activity (73).

RUNX1 forms heterodimers with CBF $\beta$ through an RD consensus sequence, enhancing gene transcription when interacting with coactivators, including p300 and CREB-binding protein, and suppressing gene transcription when interacting with transcriptional corepressors, including Sin3A, TLE and histone deacetylases (11). The RUNX1-ETO and TEL-RUNX1 association with $\mathrm{CBF} \beta$ and $\mathrm{mSin} 3 \mathrm{~A}$ represses transcription through indirect HDAC recruitment, which removes acetyl groups from histones $\mathrm{H} 3$ and $\mathrm{H} 4$ 's lysine residues, allowing compacted or repressed chromatin formation, which reduces the accessibility of transcriptional machinery promoters (86-88). RUNX1 dissociates from $\mathrm{mSin} 3 \mathrm{~A} / \mathrm{HDAC}$ and associates with p300, reversing the process following properly stimulation (89).

The RUNX family collaborates with the SWItch/Sucrose Non-Fermentable (SWI/SNF) chromatin remodeling complex for transcriptional activation (90). RUNX1-SWI/SNF association controls gene expression during hematopoiesis, a process associated with chromatin-activating modifications, including histone $\mathrm{H} 4$ acetylation and histone $\mathrm{H} 3$ lysine 4 demethylation (90). Decreases in RUNX1 expression reduce the co-occupation of SWI/SNF, transcription activator BRG1 and SWI/SNF-related matrix-associated actin-dependent regulator of chromatin subfamily B member 1 components in RUNX1 target gene promoters; therefore, RUNX1 is important in the regulation of hematopoietic functions (90). RUNX2 also associates with SWI/SNF but through CCAAT/enhancer-binding protein $\beta$ to favor the specific transcriptional activation of osteoblastic differentiation-associated genes (91).

RUNX genes in embryonic development. RUNX genes are essential for several cell differentiation processes during mammals' development. For example, RUNXI is important for hematopoietic cell differentiation $(10,11,92)$; RUNX2 is essential for osteogenesis as a downstream effector of several signaling pathways in osteoblasts (12-14); and RUNX3 regulates neurogenesis $(93,94)$, T cell development (95) and gastric epithelium growth (15).
RUNX1 interactions with multiple proteins through its terminal $\mathrm{C}$ domain allows it to control its target gene expression, which is mainly involved in hematopoietic differentiation, ribosomal biogenesis, cell cycle regulation, and TGF- $\beta$ and p53 signaling pathways $(62,96)$. RUNX1 is essential for the definitive establishment of hematopoiesis during embryogenic development, and is required for hematopoietic stem and progenitor cell regulation (97). In adults, RUNX1 serves a role in lymphocyte and megakaryocyte maturation. The polycomb group-polycomb repressive complex 1 core complex and polycomb group RING finger protein 1 (Pcgf1) inhibit progenitor cell self-renewal by negatively regulating homeobox protein Hox genes, whereas RUNX1 drives cell differentiation where self-renewal has been limited by Pcgf (97). RUNX1 and Pcgf1 joint action demonstrates a required epigenetic and transcriptional regulation association for hematopoietic differentiation (97). The cell differentiation of myeloid progenitors into granulocytes requires RUNX1, meanwhile the absence or reduction of RUNX1 expression activates cell proliferation $(98,99)$.

Specific RUNX2 levels contribute to cell cycle entry, exit and progression in osteoblasts and endothelial cells (100). RUNX2 suppresses pre-osteoblast proliferation, affecting cell cycle progression in the G1 phase $(100,101)$. RUNX2 acts as a master regulator for osteoblastic lineage formation, either directly or indirectly controlling key gene expression (collagen 1, osteocalcin, osteopontin, alkaline phosphatase and bone sialoprotein) for early differentiation of osteoblasts (12). Osteoblastic lineage progression from pluripotent mesenchymal cells to mature osteocytes is regulated by multiple physiological signals, including transforming growth factor (TGF) $\beta$, bone morphogenetic protein, vitamin D and glucocorticoids (102). RUNX2 expression is very high in hematopoietic stem cells, even higher than RUNX1, but decreases during myeloid differentiation (103). RUNX2 also regulates lymphoid lineage in the early stages and $\mathrm{B}$ cell differentiation $(104,105)$.

$R U N X 3$ expression is characterized by spatial and temporal changes, and has been observed in epithelial and mesenchymal cells, especially in the peripheral nervous system, dorsal ganglion root neurons, adult gastrointestinal tract epithelial cells and hematopoietic cells (39). Its function is associated with controlling gastric epithelial cell growth and differentiation (15), cytotoxic lineage thymocyte epigenetic silencing (106), lineage specification, and cluster of differentiation (CD)8 lymphocyte homeostasis as well as supporting bone cell development and differentiation (107).

RUNX and cancer. RUNX protein aberrant expression and mutations have been associated with different types of cancer, where they may act as tumor suppressors and oncogenes depending on the biological context (9). Additionally, in fibroblasts with overexpressed RUNX proteins, their ability to regulate multiple targets associated with specific functions during oncogenesis and development was demonstrated (108-110).

RUNX1 and leukemia. RUNX1 haploinsufficiency causes a predisposition to leukemia, but its overexpression is necessary for solid tumor formation in the skin, lungs, intestines and 

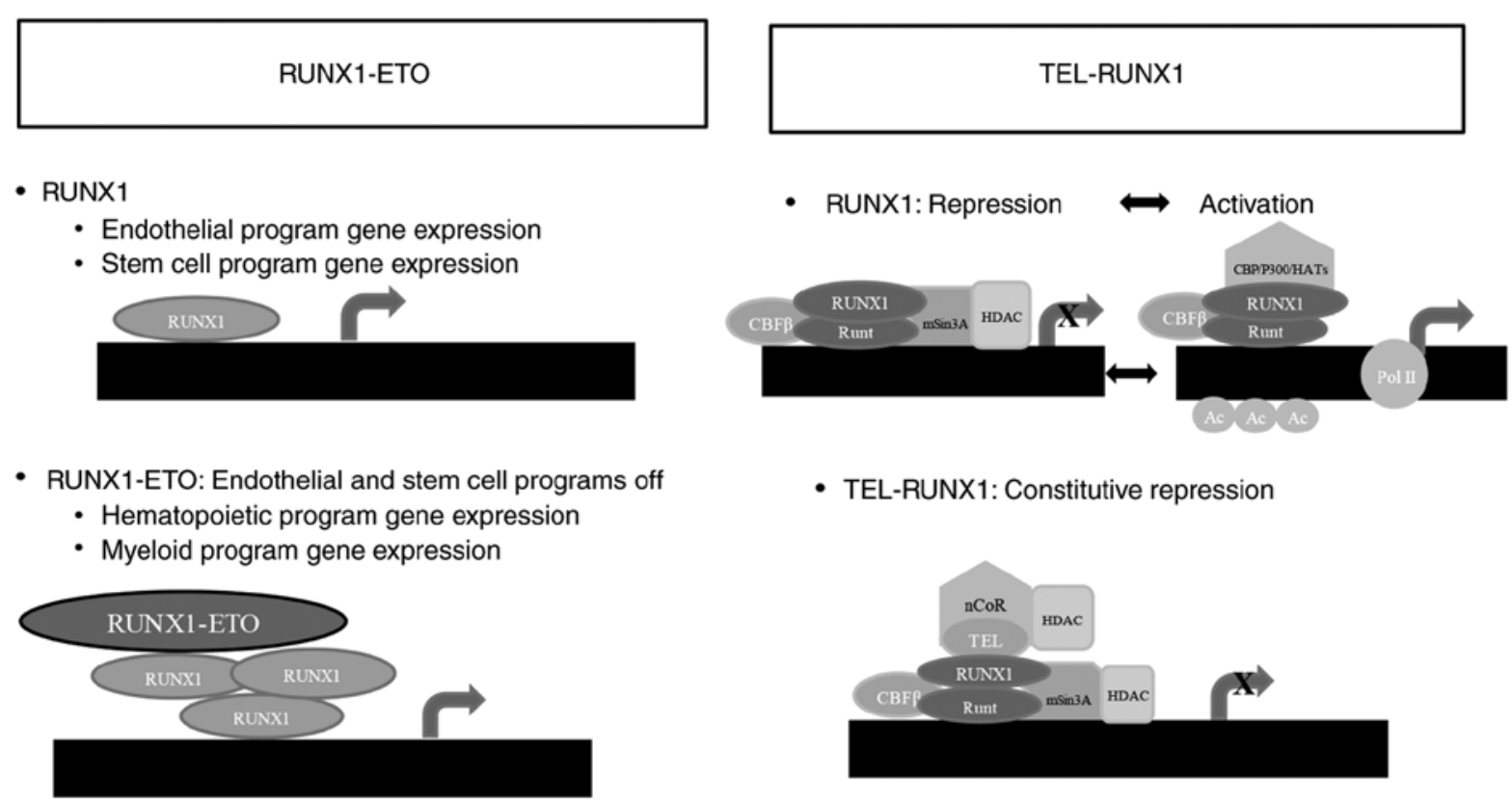

- TEL-RUNX1: Constitutive repression

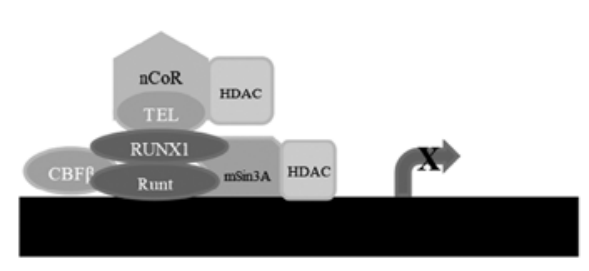

Figure 2. Two RUNX1 fusion proteins and their role in carcinogenesis. RUNX1 alters its normal molecular action by forming different complexes (RUNX1-ETO, TEL-RUNX1), and activating and/or inhibiting specific groups of genes. Figure adapted from Fig. 8 in reference (114) and Fig. 5 in reference (89). RUNX, runt-related transcription factor.

breasts $(19,20,111)$. Leukemia development has been associated with $R U N X 1$ point mutations, amplifications and translocations (16-18). RUNX1 frequent chromosomal translocations in leukemia generate unique fusion proteins with great oncogenic potential that affect the TAD, but not the RD, making RUNXI a dominant negative inhibitor (17).

$R U N X 1$ is the gene most frequently affected by chromosomal translocations in leukemia $(112,113)$. The multiple RUNX1 translocations associated with leukemia are $\mathrm{t}(8 ; 21)$ [Runx1-protein CBFA2T1 (ETO/MTG8)], $\mathrm{t}(16 ; 21)$ (Runx1-MTG16), $\mathrm{t}(3 ; 21)$ [Runx1-MDS1 and EVI1 complex locus protein (Evi1)], $\mathrm{t}(12 ; 21)$ [transcription factor ETV (TEL)-Runx1], and $\mathrm{t}(\mathrm{X} ; 21$ ) (Runx1-zinc finger protein ZFPM2) (11). Acute lymphoid leukemia (ALL) is characterized by a myeloid differentiation blockage in which the RUNX1-ETO fusion protein is associated with its onset and interferes with normal RUNX1 activator and repressor functions in the early and late stages of hematopoietic cell development (114). In a proposed model of RUNX1-ETO-mediated gene expression, there were changes in two different target cell types after RUNX-ETO induction that led to an interference in RUNX1 target myeloid regulatory gene downregulation, and to a failure in the overexpression of hematopoietic genes, endothelial gene repression and the negative regulation of stem cell programs (Fig. 2) $(89,114)$. ALL in children is associated with TEL/AML1 (115). The TEL-RUNX1 protein retains the ability of the RUNX1 RD to bind to its target sequences, and the ability of TEL to dimerize and bind to corepressors $\mathrm{n}$-Cor and $\mathrm{mSin} 3 \mathrm{~A}$, forming a very stable repressor complex dependent on HDACs that allow the chimeric protein to resist RUNX1 normal regulation, causing RUNX1 target gene deregulation (Fig. 2) $(89,114)$. The $A M L 1 / R U N X 1$ gene is also involved in acute myeloid leukemia (AML) through its translocation $\mathrm{t}(3 ; 21)$ AML1-Evi1, which is also associated with myelodysplastic syndrome and chronic myelogenous leukemia blast crisis $(116,117)$. RUNX1 mRNA levels were higher and more variable in blood samples of 58-year-old female patients with AML compared to male patients with AML from the Hematology Clinic at the Medical University of Lodz (Poland) (118).

In the majority of cases, chimeric genes that involve the RUNX1 locus inhibit its function, but it's function is increased in other cases $(18,119)$. If RUNX1 chimeric genes inactivate the function of RUNX1 to cause leukemia, then functional loss by mutations must also cause acute myeloid leukemia; in fact, patients with different types of leukemia possess heterozygous or homozygous sporadic and familial mutations $(120,121)$. However, an extra RUNX1 copy in megakaryoblastic leukemia associated with Down syndrome in newborns and children generates RUNX1 overexpression, which can also lead to leukemia development (122).

Germline monoallelic mutations in RUNX1 have been linked to acute myelogenous leukemia and its incidence is comparable with other translocations, including t(8;21) AML M2 subtype and the inv (16) AML M4Eo subtype (16). In half of the cases of AML (M0 subtype), point mutations located in the RD were biallelic with a frequency that varied depending on ethnicity and that led to DNA binding (16). Here, the union to the $\beta$ subunit remains active, which explains the presence of dominant negative effects (16). RUNX1 is one of the genes with the highest number of mutations in luminal type breast cancer, according to whole genome sequencing and whole exome sequencing studies in tumor, normal adjacent tissue and peripheral blood of patients from the Institute of Breast Disease of the FUCAM A.C. Hospital, and fresh frozen Vietnamese samples from the BioServe commercial tissue repository (123). The countersense mutations in the RUNX1 $\mathrm{RD}$ and $\mathrm{CBF} \beta$ indicate their transcriptional capacity in addition to their influence on breast cancer growth $(123,124)$. Alkylating agent-conjugated pyrrole-imidazole polyamides 
specifically bind to consensus RUNX-binding sequences to inactivate all RUNX family members, inhibiting the maintenance and progression of AML cells (125). Small molecule inhibitors of CBF $\beta$-RUNX1 affect RUNX1 occupancy on its target genes, and therefore the expression RUNX1 target genes in leukemia and basal-like breast cancer cells (126).

RUNX2, osteosarcoma, and breast, prostate and lung cancer. RUNX2 protein is the only one in the family that has a polyglutamine-polyalanine motif at the $\mathrm{N}$-terminal prior to the $\mathrm{RD}$, which has been associated with the formation of spiral structures, and aggregation and toxicity during the establishment of human genetic diseases (127). RUNX2 oncogenic activity was first demonstrated in transgenic mice, where it was associated with T-cell lymphoma induction when there was Myc proto-oncogene protein (c-Myc) ectopic expression (128).

The $R U N X 2$ chromosomal region 6p12-p21 is amplified in osteosarcoma of long bones from children between 4 and 15 years old (21), associating it with increased tumorigenicity and metastasis, and reduced survival rates $(21-23,129,130)$. Bone growth-associated genes in metastatic cancer help tumor cell development in osteosarcoma $(131,132)$. RUNX2 expression has been consistently altered in papillary and thyroid carcinomas in patients between 22 and 87 years of age from the Endocrine Unit of Internal Medicine of 'Azienda Ospedaliera Universitaria Integrata of Verona' $(24,25)$. RUNX2 silencing in thyroid carcinoma decreased molecules associated with the epithelial-mesenchymal transition (EMT) process and angiogenic factors (133). RUNX2 positively regulates survivin, an apoptosis inhibitor, which allows tumor cell survival in vitro (134).

In breast and prostate cancer, RUNX2 is overexpressed and associated with an increase in metastatic capacity (26-28). RUNX2 expression increases markedly in neoplastic breast cells, especially in metastatic cells (135). RUNX2 increases breast tumor cell metastatic capacity by increasing the expression of several factors, including vascular endothelial growth factor, matrix metalloproteases (MMP2, MMP9 and MMP13) and bone sialoprotein (BSP), facilitating the process (136). CADD522 was a identified from a computer-assisted drug design screen as cholecalciferol (a prohormone and precursor of 25-OH Vitamin D3 prohormone) (137) and is a small molecule capable of inhibiting RUNX2 expression through the blockade of its protein domain or binding pocket interactions, leading to growth inhibition, clonogenic survival, tumorsphere formation and the invasion of breast cancer cells (138).

Bone morphogenetic protein-3b (BMP-3b/GDF10) is a tumor growth inhibitor and a member of TGF $\beta$ family (139). $R U N X 2$ is highly expressed in lung tumor cells that negatively regulate BMP-3b (139). The molecular mechanism that mediates BMP-3b suppression by RUNX2 is based on the recruitment of histone-lysine N-methyltransferase SUV39H1 to the BMP-3b proximal promoter of the specific methyltransferase for histone $\mathrm{H} 3$ lysine 9 (H3K9), which increases methylation levels (139). In RUNX2 knockout H1299 cells, a significant decrease in $\mathrm{H} 3 \mathrm{~K} 9$ methylation levels at the BMP-3b promoter was observed, thereby increasing BMP-3b expression levels (139). Meanwhile, RUNX2 overexpression increased the wound healing process in response to TGF- $\beta$. One study suggests that RUNX2 is a potential therapeutic target to block tumor suppressor gene silencing in lung tumor cells (139). However, it is necessary to include clinical studies to prove this hypothesis in patients.

RUNX3 and gastric cancer. RUNX3 is located in a chromosomal region identified as a tumor suppression center, where there are a large number of genes that are inhibited during different tumor processes, due to its ability to positively regulate other tumor suppressor genes (140). RUNX3 nonspecific localization in the cytoplasm has been reported as the major form of RUNX3 inactivation (141) due to Src tyrosine kinase activation, as has been observed in cancer cell lines (142) in addition to gastric (141) and breast cancer cells from patients of the University Hospital Tissue Repository and the Pathology Department, National University of Singapore (143). Therefore, RUNX3 expression in tumor stroma has been associated with a good clinical prognosis (144).

For several years, RUNX3 was considered a tumor suppressor repressed in gastric cancer, beginning with a study of patients from the Department of Digestive Surgery, Kyoto Prefectural University of Medicine and the National Cancer Center Hospital (Tokyo) (145). Over 200 publications support the conclusion of Li et al (145), suggesting RUNX3 tumor suppressor function in cancer. For example, RUNX3 restored expression by histone-lysine $\mathrm{N}$-methyltransferase EZH2 knockdown resulted in decreased gastric cancer (adenocarcinoma stage IA, IB, II, IIIA, IIIB and IV) cell proliferation associated with RUNX3 promoter demethylation (146). Chronic inflammation caused by Helicobacter $(H$.) pylori infection coupled with its virulence factors has been demonstrated to lead to promoter methylation and the silencing of numerous tumor suppressor genes, among which is the RUNX3 P2 CGI $(147,148)$. RUNX3 anti-tumor activity has been pharmacologically restored by DNA methyltransferase inhibitors and histone deacetylases (39). In addition, the effect of docetaxel/cisplatin and capecitabine administration on RUNX3 methylation levels in the serum of patients with stage II and III gastric and lower oesophageal adenocarcinoma was evaluated to assess its role as a biomarker in response to treatment (149). Inflammation is a well-established oncogenic factor in the stomach (150). RUNX3 associates with the TNF- $\alpha / N F-\kappa B$ signaling pathway during $H$. pylori infections to directly overexpress IL-23A in gastric epithelial cells (150). It is unknown why IL-23A is secreted alone in gastric epithelial cells, but RUNX3 induces IL-23A expression, which suggests a role for RUNX3 in innate immunity where it increases pathogen elimination during infection and inflammation, ultimately protecting the stomach epithelium (150). However, the heterodimeric cytokine IL-23, which consists of IL-23B and IL-23A, cannot be formed (150).

A RUNX3 point mutation has been directly associated with its tumor suppressor function in gastric cancer since the substitution of an arginine for a cysteine (R122C) leads to the complete loss of its tumor suppressor activity (145). In gastric cancer tissue, the R122C mutation has been found in the conserved RUNX3 RD (145), a mutation found also in head and neck cancer, according to The Cancer Genome Atlas project of Head and Neck Cancer (151). RUNX3 expression with the R122C mutation does not inhibit tumor growth but increases tumorigenic activity beyond the parental gastric 
cancer cell line level because it seems that an amino acid substitution is enough to convert a strong tumor suppressor into an oncogene (145). RUNX3 exogenous expression in cultured cell lines has been associated with growth inhibition, very similar to the p53 tumor suppressor, which suggests that RUNX3 also has tumor suppressor activity (39). Recently, RUNX3 has been suggested as a possible protector of the genome, like $\mathrm{p} 53$, since they are involved in tumor suppressor functions and oncogene surveillance (152). During DNA damage, RUNX3 participates in p53 phosphorylation and acetylation, and during oncogene activation, RUNX3 promotes ARF to stabilize p53 (153). Epstein-Barr nuclear antigen 2 (EBNA2) is a transcription factor encoded by the Epstein-Barr virus, which is associated with B-cell lymphomas (154). EBNA2 targets a specific element within a super-enhancer of RUNX3 to positively regulate it, depending on the Notch DNA-binding partner recombining binding protein suppressor of hairless expression. Then, $R U N X 3$ represses $R U N X 1$ to control B-cell growth $(155,156)$.

However, RUNX3 tumor suppressor function in gastrointestinal tumors continues to be debated because $R U N X 3$ demonstrates low expression in the normal gastric epithelium, as demonstrated by multiple techniques, including in situ hybridization and immunohistochemistry $(67,141,157)$, as well as the majority of gastric cancers $(45-60 \%)$ in humans $(19,145)$. Low expression of RUNX3 in normal and tumoral tissues is considered to be inconsistent with a tumor suppressor function, as researchers consider that it should be expressed in normal tissue and repressed in cancer to fulfill a tumor repressor function (158). However, a new model of $R U N X 3$ regulation in gastric cancer has been proposed based on RUNX3 P1 hypermethylation observed in normal gastric epithelium and RUNX3 P1 hypomethylation identified in cytotoxic lymphocytes infiltrating preneoplastic and tumor epithelia (64); this is also supported by the dependence of $\mathrm{CD}^{+} \mathrm{T}$-cells and $\mathrm{NK}$ cell cytolytic functions on RUNX3 expression (159), suggesting that this transcription factor could be used as a prognostic marker (67).

Pancreatic ductal adenocarcinoma (PDAC) studies may have helped solve the inconsistences in RUNX3 tumor suppressor function, as they suggest that it is instead a switch for metastatic control $(160,161)$. Studies demonstrating RUNX3 as a tumor suppressor (145) and as an oncogene (157) demonstrate its dual role in cancer, as in PDAC where it acts as a tumor suppressor slowing proliferation and as an oncogene promoting metastasis and invasion, controlling the balance of local growth and metastasis in primary and metastatic tumors (160). RUNX3 expression has been associated with mothers against decapentaplegic homolog 4 (SMAD4, also known as DPC4) copy number variants, and level patterns have been directly associated with relapse and the response to therapies (160). RUNX3 expression has also been associated with combined epigenetic programs and metabolic processes when it is part of the retinoic acid receptor $\beta /$ RUNX3/collagen $\alpha-1(\mathrm{VI})$ chain signal axis, linking hypoglycemia with local invasion and angiogenesis, and hyperglycemia with metastatic colonization (162).

RUNX3 suppression in normal cells does not have a direct implicated function, but it could be associated with improved cancer cell viability and growth (163). RUNX3 suppression in gastric cancer must affect both alleles to be severe enough to develop the disease (164). RUNX3 overexpression in several types of cancer, as in pancreatic cancer cells, promotes migration, growth and metastasis, while in head and neck squamous cell carcinoma tissues, it promotes cell growth and tumor sphere formation, as well as inhibiting apoptosis (165). The contradictory and debated function of RUNX3 as a tumor suppressor in gastric cancer and other types of cancer has led researchers to consider its role in the maintenance of immune cells and the control of inflammation, suggesting that it could be a regulator of the tumor immune microenvironment and epithelial tumor development (166).

$R U N X$ 's regulation of cellular pathways. RUNX1 is highly expressed in the mesenchymal and epithelial compartments of embryonic and postnatal lungs with lipopolysaccharideinduced lung inflammation, regulating the NF- $\mathrm{NB}$ signaling pathway through the interaction with the inhibitor of nuclear factor- $\kappa \mathrm{B}$ kinase (IKK) complex or the $\mathrm{NF}-\kappa \mathrm{B}$ subunit $\mathrm{p} 50$ in the cytoplasm (Fig. 3) $(7,60,167,168)$. RUNX1 is targeted in mesenchymal and epithelial compartments of the skin during embryogenesis, deregulating lymphoid enhancer-binding factor (Lef)1 and protein Wnt (Wnt) signaling in opposite directions, decreasing Lef1 and activating canonical Wnt signaling (169). RUNX1 controls the epidermal growth factor receptor (EGFR) signaling pathway in non-small-cell lung cancer cells, regulating ERBB receptor feedback inhibitor 1 expression, which is a negative feedback regulator of the EGFR phosphorylated form (Fig. 3) $(7,60,167,168,170)$. RUNX1 translocates to the cytoplasm to form a complex with IKK $\beta$ that inhibits the $N F-\kappa B$ signaling pathway (Fig. 3) $(7,60,167,168)$

The neurogenic locus notch homolog protein (Notch) signaling pathway is important for cell fate (170). Notch is associated with the increase in $\mathrm{NF}-\kappa \mathrm{B}$ expression, activating zinc finger protein SNAI1 and EMT, and stabilizing $\beta$-catenin (171). The Notch1-4 receptor has an extracellular and an intracellular (NICD) domain that binds to the Notch ligand [delta-like protein (DLL)/jagged (JAG)] from a different cell, releasing its NICD, which translocates to the nucleus and interacts with CSL [acronym for recombining binding protein suppressor of hairless (also known as CBF1)/suppressor of hairless protein/DNA-binding protein LAG-1 (Figs. 3 and 4) (7,60,167,168,172-175). The NICD-CSL complex displaces corepressors and recruits mastermind-like protein (MAML) to form the Notch-CSL-MAML complex, which recruits members of the Notch transcriptional complex to activate gene expression (176). RUNX1 is regulated by Notch1 in NIH3T3 cells (177), in hematopoietic stem cell development (178) and in mesodermal cells (179). RUNX2 inhibits the Notch signaling pathway during normal osteoblast differentiation (180) and during bone remodeling, and regulates osteopontin in osteoblastic cells (181). RUNX3 is a direct target of Notch in endothelial cells (182).

The Wnt signaling pathway is important for stem cell differentiation processes (183). Wnt binds to frizzled, thereby activating dishevelled, inhibiting glycogen synthase kinase $3 \beta$, and avoiding $\beta$-catenin phosphorylation and destruction (7). Then, $\beta$-catenin can enter the nucleus, providing a transcriptional activation domain to Lef1 [also known as T-cell factor 




Figure 3. Signaling pathways related to RUNX1. RUNX1 has been involved in NF-kB pathway. Figure adapted from Fig. 2 in reference (7), Fig. 2 in reference (60), Fig. 2 in reference (167) and Fig. 2 in reference (168). RUNX, runt-related transcription factor.

(TCF)1] to induce EMT regulator transcription, including SNAI1, SNAI2 and vimentin (Figs. 3-5) $(7,60,167,168,184)$. The RUNX1 P1 isoform is increased through Wnt/ $\beta$-catenin signal induction in HL60, Jurkat leukemia-derived cell lines and $\mathrm{CD} 34^{+}$progenitors, and is likely important during normal hematopoiesis or malignant cell transition during leukemia onset or progression (185). RUNX1-ETO stimulates gene regulation mediated by transcription factor-4 (TCF-4) or TCF-dependent transcription during Wnt signaling, inhibiting ETO function (186).

In osteoblasts and chondrocytes, Wnt signaling induces differentiation and chondrocytic hypertrophy through $R U N X 2$ positive regulation (187), whereas during osteogenesis, $R U N X 2$ is a direct target of $\beta$-catenin/Lef1 to stimulate bone formation (188). Wnt signaling is associated with TGF- $\beta$ signaling (189). $\beta$-catenin and the SMAD2/3-SMAD4 complex can activate Lef1, behaving as a molecular node that links the Wnt signaling pathway with other signaling pathways associated with EMT (7). RUNX3 can activate the Wnt signaling pathway to control TCF- $4 / \beta$-catenin complex stabilization on the Wnt target gene promoter, suppressing tumorigenesis in KatoIII cells; however, RUNX3-TCF- $4 / \beta$-catenin complex binding can also repress the Wnt signaling pathway depending on cell context mechanisms (190). 


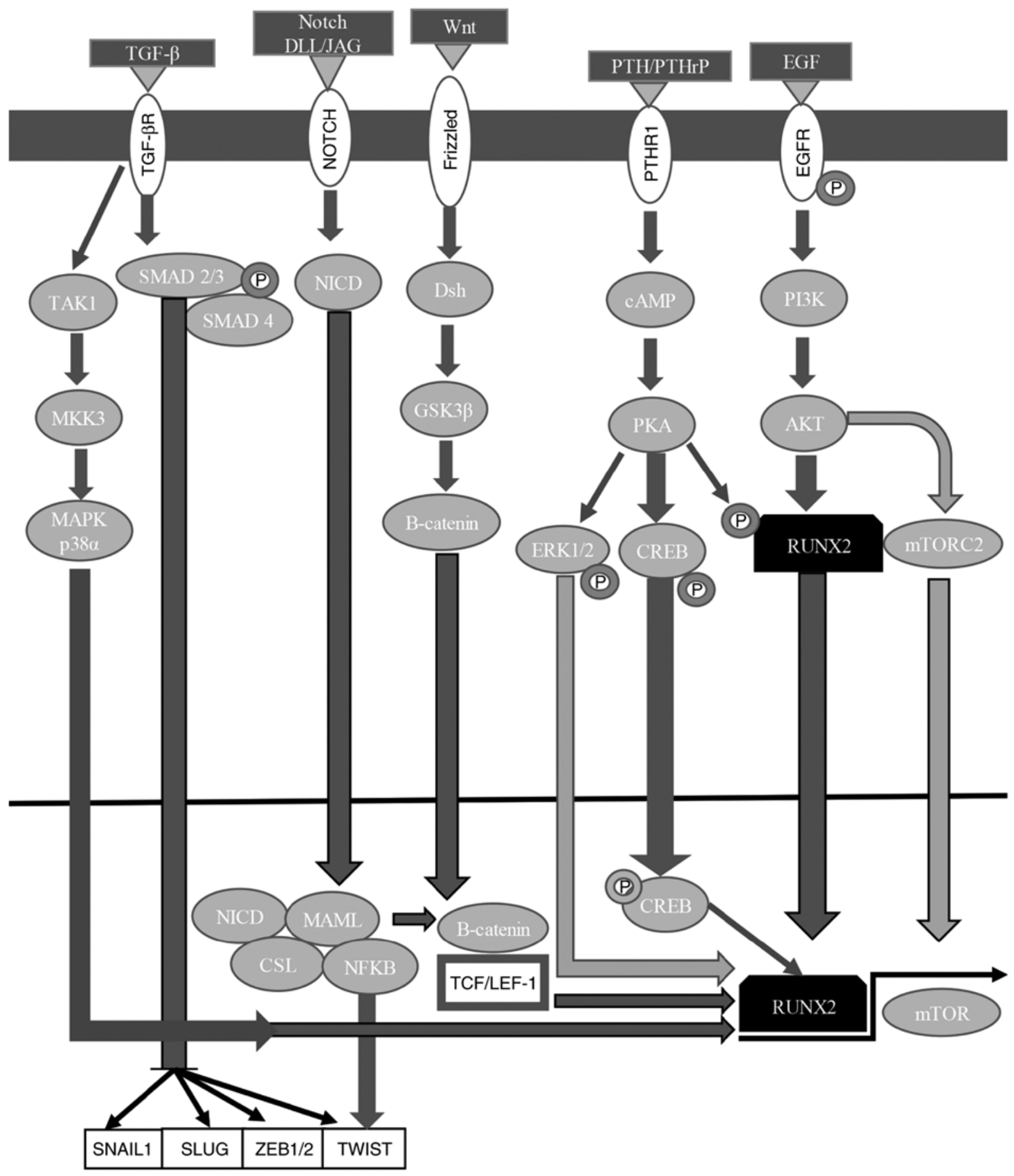

Figure 4. Signaling pathways related to RUNX2. RUNX2 has been involved with TGF- $\beta$ pathway. Figure adapted from Fig. 2 in reference (172), Fig. 2 in reference (167), Fig. 2 in reference (7), Fig. 4 in reference (173), Fig. 1 in reference (174) and Fig. 2 in reference (175). RUNX, runt-related transcription factor.

RUNX1 and RUNX3 tumor suppressor activities are mediated in part by estrogen signaling antagonism, as previously described regarding RUNX2 activity (191). RUNX1 interacts with estrogen receptor (ER) $\alpha$ to attenuate estrogen signaling (Fig. 3) (7,60,167-169). RUNX1 positively regulates the receptor tyrosine-protein kinase erbB-2 (ErbB2/HER2) signaling pathway in gastric cancer by binding to the son of sevenless homolog 1 (SOS1) promoter. Therefore, RUNX1 knockdown is associated with decreased SOS1 expression and ErbB2/HER2 dephosphorylation, which suppresses gastric cancer cell proliferation (192). RUNX2 has been demonstrated to reduce
ER $\alpha$ (also known as ESR1) activity, binding to the ESR1 gene promoter (193). Furthermore, RUNX2 is inhibited by estrogens, which may help to explain their context-dependent non-osseous anti-metastatic roles, as ER $\alpha$ is only associated with the increased skeletal dissemination of breast cancer cells (194). RUNX2 regulates cAMP-associated G-protein-coupled receptor signaling, activating the G-protein coupled estrogen receptor 1 gene and repressing the expression of the regulator of G-protein signaling 2 gene in osteoblasts to respectively increase and reduce mitogenic signal sensitivity, allowing cell cycle progression and osteoblastic lineage commitment (195). 


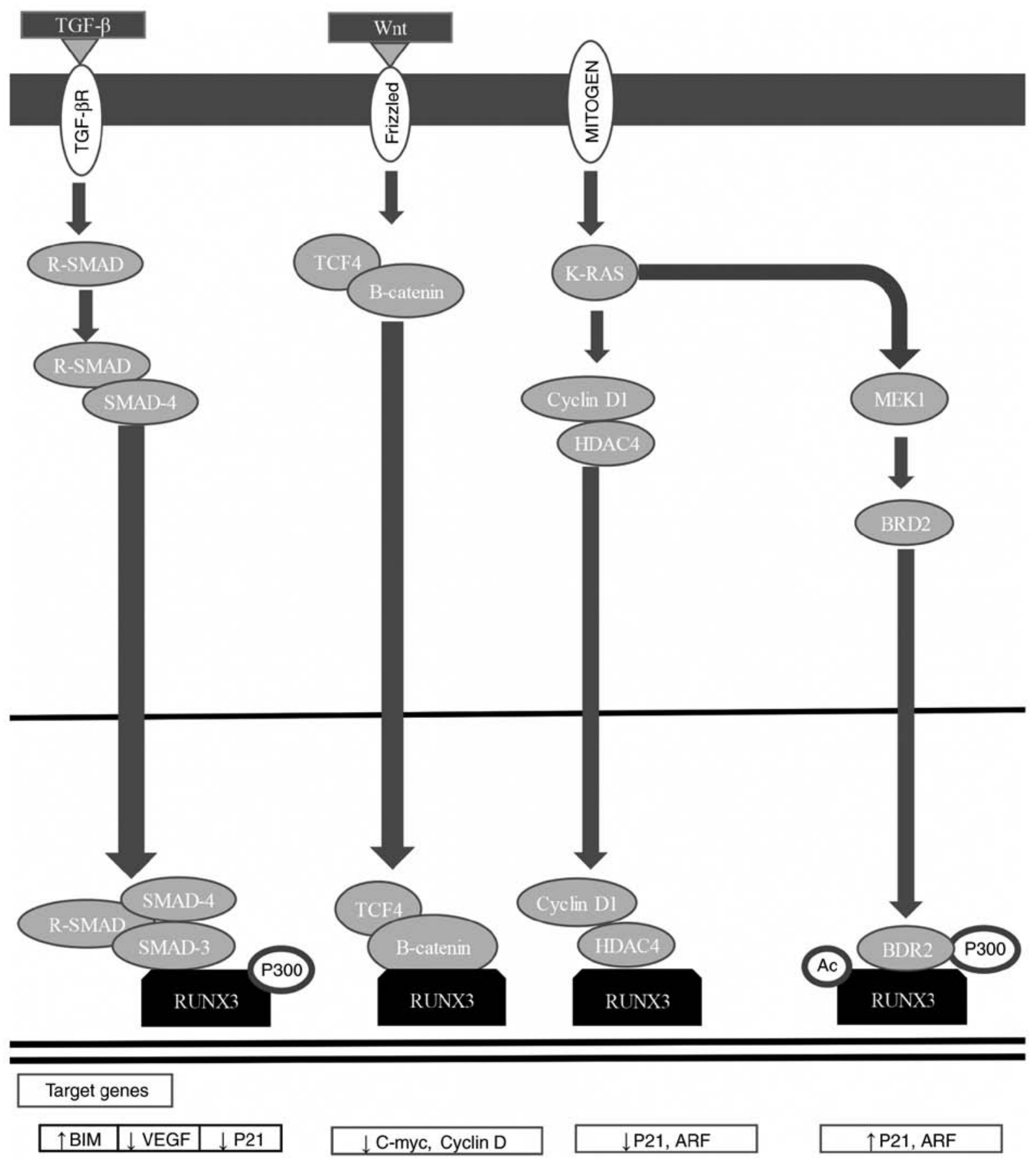

Figure 5. Signaling pathways related to RUNX3. RUNX3 has been involved with TGF- $\beta$ pathway. Figure adapted from Figs. 1, 2 and 3 in reference (184). RUNX, runt-related transcription factor.

RUNX3 mediates ER $\alpha$ ubiquitination and degradation (144), possibly because the binding of RUNX3-ER $\alpha$ alters its posttranslational modifications, changing its stability $(196,197)$ or facilitating E3 ligase (E3 ubiquitin-protein ligase Mdm2 and Smurfs) recruitment (Fig. 5) (144,184,198,199). RUNX3 inhibits the estrogen-dependent proliferation and transformation potential of ER $\alpha$-positive MCF-7 breast cancer cells, reducing ER $\alpha$ stability (200).

RUNX2 is phosphorylated/activated by cAMP-dependent protein kinase (PK)A and MAPK signaling pathways; it is also enhanced by factors that stimulate signal transduction pathways, including parathyroid hormone/parathyroid hormone-related protein from the PKA and PKC signaling pathways, and BMPs of Smad proteins, suggesting a fundamental role in directing osteoblast differentiation (173). RUNX2 has been associated with metastasis in breast cancer, activating SNAI2 expression in the TGF- $\beta$ and Wnt signaling pathways (194). RUNX2's interaction with the phosphatidylinositol 4,5-bisphosphate 3-kinase/RAC- $\alpha$ serine/threonine-protein kinase (PI3K/AKT) signaling pathway is essential to control cancer growth and metastasis, where AKT phosphorylates/activates RUNX2 or phosphorylates/inactivates RUNX2 regulators (Fig. 4) (7,167,172-175). RUNX2 also activates the PI3K/AKT signaling pathway, regulating its different components in non-transformed and transformed cells (175). Therefore, AKT activation and high 
levels of RUNX2 may induce tumor progression and aggressiveness (Fig. 4) (7,167,172-175,199).

RUNX3 is a downstream effector of the TGF- $\beta$ signaling pathway, and has critical functions in apoptosis regulation, angiogenesis, EMT, and cell migration and invasion processes (184). RUNX3 functions as an initiator of tumorigenesis, participating in the Wnt oncogenic signaling pathway and the TGF- $\beta$ tumor suppressor signaling pathway (Fig. 5) (184,196). RUNX3 associates with SMAD3/SMAD4 to activate growth inhibition reliant on TGF- $\beta$ and apoptosis by p21 and Bcl-2-like protein 11 induction (Fig. 4) (7,167,1 72-175,201-203). RUNX3 inhibits the oncogenic signaling pathway by forming a complex with TCF-4/ $\beta$-catenin, which avoids binding to its target gene promoters [c-Myc and G1/S-specific cyclin D1 (cyclin D1)], regulating apoptosis and the cell cycle (Fig. 5) (184,204). RUNX3 inhibits EMT, avoiding the Wnt signaling pathway $(184,205,206)$. Mitogenic stimulation induces RUNX3-bromodomain-containing protein 2 (BRD2) complex formation, and p21 and ADP-ribosylation factor (ARF) expression, while a decrease in GTPase KRas (K-Ras) signaling pathway activation and an increase in cyclin D1 converts the RUNX3-BRD2 complex into a RUNX3-HDAC4 complex, shutting down ARF and p21 expression (184,207). When K-Ras is constitutively activated, the oncogenic Ras-activated dual specificity mitogen-activated protein kinase kinase 1 signaling pathway inhibits conversion between complexes, keeping ARF1 and p21 expression active (Fig. 5) (184,207).

\section{RUNX family dual role in cancer}

Transcription factor coding genes are deregulated in cancer since they can be amplified, deleted, chromosomally translocated and affected by point mutations $(5,7)$. Transcription factors deregulatory mechanisms in cancer suggest its importance in aberrant gene expression during cell transformation and justify considering them as therapeutic targets.

RUNX genes have proved to be essential regulators of cell fate in development but have opposite effects in cancer, acting as dominant oncogenes or tumor suppressors $(30-32,39,208,209)$. RUNX protein complexes control the expression of multiple genes by binding to their promoters or enhancers, which are relevant for cell fate, a feature that may also be involved in tumor cell gene regulation (77). RUNX complex regulation is lineage and stage specific, and includes crucial decisions between stopping the cell cycle and continuing with proliferation, and between differentiation and self-renewal (9).

RUNX can act as an expression activator or repressor of a specific target gene, depending on the interacting coactivators or corepressors, since RUNX proteins can join and recruit a large group of them and regulate target promoters (11). RUNX proteins have some common characteristics in the transactivation/inhibition domains and in some specific conserved motifs, including the nuclear-matrix binding signal and VWRPY motif that interacts with corepressors (210). In general, the conserved RD and the divergent $\mathrm{C}$-terminal domains (Fig. 1) (44) suggest that RUNX proteins have a redundant function in some cellular contexts and that they exert unique effects in others $(9,211)$.
The majority of the genes involved in cancer etiology are classified as oncogenes or tumor suppressors; however, RUNX genes have not been classified within either of these groups, as there is experimental evidence of a dual function in different types of cancer $(9,31,32)$. The suppressed expression of RUNX genes in some types of cancer has been associated with the presence of inactivating mutations, gene deletions and hypermethylation, whereas retroviral insertion in murine models has been associated with gene activation (119).

RUNX family oncogenic potential can be based on the fact that the family has diverged evolutionarily in function, or that its functions arose from the develop of specific controls in its gene expression (9). Trials with transcriptional reporters demonstrated essentially identical effects of the three genes in a series of target promoters, and hematopoietic development rescue by the knock-in of coding exons at RUNX2 and RUNX3 3 'end in $R U N X 1$, which reveal at least a partial functional overlap $(212,213)$.

Experimental evidence suggests that $R U N X$ genes may be dominantly oncogenes. First, RUNX1 chromosomal translocations in hematopoietic cancer form oncogenic lineage-specific fusion proteins, which inhibit normal functions of the RUNX complex (11). Second, there is important experimental evidence suggesting that $R U N X$ gene deregulated expression comes from retroviral insertions in murine lymphomas $(214,215)$. Third, $R U N X$ 'wild-type' genes are oncogenic in transgenic mice, depending on dose (209). Fourth, RUNX1 has functional amplification relevance in hematological diseases (62). Likewise, there is important evidence on function loss in cancer, since RUNX1 fusion proteins can antagonize 'wild-type' gene function and RUNX3 mutations reduce RUNX3 function (145).

The contrasting roles of RUNX proteins can be explained by generating specific biological contexts for lineage and cancer or the developmental stage at which these abnormalities have been detected. For example, myeloid leukemia cases are associated with chromosome 21 polysomies and with RUNX1 amplification (216). In addition, lymphoid neoplasms have been demonstrated to be activated by the proviral insertion murine RUNX genes and RUNX1 amplification in humans (32).

\section{Conclusions}

Scientific research on cancer has revealed that the oncogenic potential of RUNX proteins depends on specific gene expression patterns at different types and stages of cancer (217). RUNX family oncogenic potential can be based in principle on its gene structure, which allows them to use different promoters and perform alternative splicing for the formation of multiple isoforms (42). RUNX protein isoforms can provide specific characteristics to act as transcription factors with the ability to regulate a certain number of genes involved in oncogenic signaling pathways.

The ability of RUNX proteins to form functional complexes with other proteins can enable them to activate and repress the transcription of key process regulators associated with oncogenic development, including cell growth and cell differentiation. Likewise, posttranscriptional modifications in RUNX protein expression regulation, which is associated 
with their overexpression and functional loss, may partially demonstrate the dual function of these transcription factors (9).

Experimental evidence on the dual function of RUNX in cancer suggests that the therapeutic control of their expression can change their oncogenic function and turn them into tumor suppressor genes, leading them to positively regulate tumor suppressor genes and negatively regulate oncogenes, reversing the tumorigenic processes in patients $(39,125)$. Likewise, RUNX proteins could be identified as a group of relevant biomarkers that could be used to developearly detection techniques (39). The experimental determination of the molecular context in which RUNX proteins change their oncogenic function into tumor suppressors is the key to their use as biomarkers and therapeutic targets in cancer treatment.

\section{Acknowledgements}

Not applicable.

\section{Funding}

The current review was funded by the grant number 8740 from Pontificia Universidad Javeriana. The work of the author BAOO is supported by the doctoral fellowships given by The Administrative Department of Science, Technology and Innovation of Colombia.

\section{Availability of data and materials}

Not applicable.

\section{Authors' contributions}

AR conceptualized the design of the present review. BAOO did the literature search and contributed to the manuscript writing. BH and LLK made several revisions of the text, making crucial contributions to the scientific analysis and discussion of the thesis presented in the review. All authors approved the final manuscript.

\section{Ethics approval and consent to participate}

Not applicable.

\section{Patient consent for publication}

Not applicable.

\section{Competing interests}

The authors declare that they have no competing interests.

\section{References}

1. Hanahan D and Weinberg R: Hallmarks of cancer: The next generation. Cell 144: 646-674, 2011.

2. Hanahan D and Weinberg R: The hallmarks of cancer. Cell 100: $57-70,2000$

3. Green G, Carmona R, Zakeri K, Lee CH, Borgan S, Marhoon Z, Sharabi A and Mell LK: Specificity of genetic biomarker studies in cancer research: A systematic review. PLoS One 11: e0156489, 2016.
4. Sharma S, Kelly TK and Jones PA: Epigenetics in cancer. Carcinogenesis 31: 27-36, 2010.

5. Bhagwat AS and Vakoc CR: Targeting transcription factors in cancer. Trends Cancer 1: 53-65, 2015.

6. Yeh JE, Toniolo PA and Frank DA: Targeting transcription factors: Promising new strategies for cancer therapy. Curr Opin Oncol 25: 652-658, 2013.

7. Darnell JE: Transcription factors as targets for cancer therapy. Nat Rev Cancer 2: 740-749, 2002.

8. Chuang LS, Ito K and Ito Y: RUNX family: Regulation and diversification of roles through interacting proteins. Int J Cancer 132: 1260-1271, 2013.

9. Blyth K, Cameron ER and Neil JC: The RUNX genes: Gain or loss of function in cancer. Nat Rev Cancer 5: 376-387, 2005.

10. Dowdy CR, Xie R, Frederick D, Hussain S, Zaidi SK, Vradii D, Javed A, Li X, Jones SN, Lian JB, et al: Definitive hematopoiesis requires Runx1 C-terminal-mediated subnuclear targeting and transactivation. Hum Mol Genet 19: 1048-1057, 2010.

11. Yamagata T, Maki K and Mitani K: Runx1/AML1 in normal and abnormal hematopoiesis. Int J Hematol 82: 1-8, 2005.

12. Lian JB, Javed A, Zaidi SK, Lengner C, Montecino M, van Wijnen AJ, Stein JL and Stein GS: Regulatory controls for osteoblast growth and differentiation: Role of Runx/Cbfa/AML factors. Crit Rev Eukaryot Gene Expr 14: 1-41, 2004.

13. Lian JB and Stein GS: Runx2/Cbfa1: A multifunctional regulator of bone formation. Curr Pharm Des 9: 2677-2685, 2003.

14. Komori T: Requisite roles of Runx 2 and Cbfb in skeletal development. J Bone Miner Metab 21: 193-197, 2003.

15. Fukamachi $\mathrm{H}$ : Run $\times 3$ controls growth and differentiation of gastric epithelial cells in mammals. Dev Growth Differ 48: 1-13, 2006.

16. Osato M: Point mutations in the RUNX1/AML1 gene: Another actor in RUNX leukemia. Oncogene 23: 4284-4296, 2004.

17. De Braekeleer E, Férec $C$ and De Braekeleer M: RUNX1 translocations in malignant hemopathies. Anticancer Res 29: 1031-1037, 2009.

18. Niini T, Kanerva J, Vettenranta K, Saarinen-Pihkala UM and Knuutila S: AML1 gene amplification: A novel finding in childhood acute lymphoblastic leukemia. Haematologica 85: 362-366, 2000.

19. Chuang LS and Ito Y: RUNX3 is multifunctional in carcinogenesis of multiple solid tumors. Oncogene 29: 2605-2615, 2010.

20. Taniuchi I, Osato M and Ito Y: Runx1: No longer just for leukemia. EMBO J 31: 4098-4099, 2012.

21. Sadikovic B, Thorner P, Chilton-MacNeill S, Martin JW, Cervigne NK, Squire J and Zielenska M: Expression analysis of genes associated with human osteosarcoma tumors shows correlation of RUNX2 overexpression with poor response to chemotherapy. BMC Cancer 10: 202, 2010.

22. Kurek KC, Del Mare S, Salah Z, Abdeen S, Sadiq H, Lee SH, Gaudio E, Zanesi N, Jones KB, DeYoung B, et al: Frequent attenuation of the WWOX tumor suppressor in osteosarcoma is associated with increased tumorigenicity and aberrant RUNX2 expression. Cancer Res 70: 5577-5586, 2010.

23. Lau CC, Harris CP, Lu XY, Perlaky L, Gogineni S, Chintagumpala M, Hicks J, Johnson ME, Davino NA, Huvos AG, et al: Frequent amplification and rearrangement of chromosomal bands 6p12-p21 and 17p11.2 in osteosarcoma. Genes Chromosomes Cancer 39: 11-21, 2004.

24. Endo T, Ohta K and Kobayashi T: Expression and function of Cbfa-1/Runx 2 in thyroid papillary carcinoma cells. J Clin Endocrinol Metab 93: 2409-2412, 2008

25. Dalle Carbonare L, Frigo A, Francia G, Davì MV, Donatelli L, Stranieri C, Brazzarola P, Zatelli MC, Menestrina F and Valenti MT: Runx2 mRNA expression in the tissue, serum, and circulating non-hematopoietic cells of patients with thyroid cancer. J Clin Endocrinol Metab 97: E1249-E1256, 2012.

26. Barnes GL, Javed A, Waller SM, Kamal MH, Hebert KE, Hassan MQ, Bellahcene A, Van Wijnen AJ, Young MF, Lian JB, et al: Osteoblast-related transcription factors Runx2 (Cbfa1/AML3) and MSX2 mediate the expression of bone sialoprotein in human metastatic breast cancer cells. Cancer Res 63: 2631-2637, 2003.

27. Barnes GL, Hebert KE, Kamal M, Javed A, Einhorn TA, Lian JB, Stein GS and Gerstenfeld LC: Fidelity of Runx 2 activity in breast cancer cells is required for the generation of metastasesassociated osteolytic disease. Cancer Res 64: 4506-4513, 2004.

28. Leong DT, Lim J, Goh X, Pratap J, Pereira BP, Kwok HS, Nathan SS, Dobson JR, Lian JB, Ito Y, et al: Cancer-related ectopic expression of the bone-related transcription factor RUNX2 in non-osseous metastatic tumor cells is linked to cell proliferation and motility. Breast Cancer Res 12: R89, 2010. 
29. Friedrich MJ, Rad R, Langer R, Voland P, Hoefler H, Schmid RM, Prinz $C$ and Gerhard M: Lack of RUNX3 regulation in human gastric cancer. J Pathol 210: 141-146, 2006.

30. Kilbey A, Terry A, Cameron ER and Neil JC: Oncogene-induced senescence: An essential role for Runx. Cell Cycle 7: 2333-2340, 2008.

31. Blyth K, Vaillant F, Jenkins A, McDonald L, Pringle MA, Huser C, Stein T, Neil J and Cameron ER: Runx2 in normal tissues and cancer cells: A developing story. Blood Cells Mol Dis 45: 117-123, 2010

32. Cameron ER and Neil JC: The Runx genes: Lineage-specific oncogenes and tumor suppressors. Oncogene 23: 4308-4314, 2004.

33. Coffman JA: Runx transcription factors and the developmental balance between cell proliferation and differentiation. Cell Biol Int 27: 315-324, 2003.

34. Sullivan JC, Sher D, Eisenstein M, Shigesada K, Reitzel AM, Marlow H, Levanon D, Groner Y, Finnerty JR and Gat U: The evolutionary origin of the Runx/CBFbeta transcription factors-studies of the most basal metazoans. BMC Evol Biol 8 : $228,2008$.

35. Nam S, Jin YH, Li QL, Lee KY, Jeong GB, Ito Y, Lee J and Bae SC: Expression pattern, regulation, and biological role of runt domain transcription factor, run, in Caenorhabditis elegans. Mol Cell Biol 22: 547-554, 2002.

36. Rennert J, Coffman JA, Mushegian AR and Robertson AJ: The evolution of Runx genes I. A comparative study of sequences from phylogenetically diverse model organisms. BMC Evol Biol 3: 4, 2003

37. Robertson AJ, Dickey-Sims C, Ransick A, Rupp DE, McCarthy JJ and Coffman JA: CBFbeta is a facultative Runx partner in the sea urchin embryo. BMC Biol 4: 4, 2006.

38. Warren AJ, Bravo J, Warren AJ and Rabbitts TH: Structural basis for the heterodimeric interaction between the acute leukaemia-associated transcription factors AML1 and CBF $\beta$. EMBO J 19: 3004-3015, 2000.

39. Ito Y, Bae SC and Chuang LS: The RUNX family: Developmental regulators in cancer. Nat Rev Cancer 15: 81-95, 2015.

40. Levanon D, Negreanu V, Bernstein Y, Bar-Am I, Avivi L and Groner Y: AML1, AML2, and AML3, the human members of the runt domain gene-family: CDNA structure, expression, and chromosomal localization. Genomics 23: 425-432, 1994.

41. Bae SC, Takahashi E, Zhang YW, Ogawa E, Shigesada K, Namba Y, Satake M and Ito Y: Cloning, mapping and expression of PEBP2 alpha C, a third gene encoding the mammalian Runt domain. Gene 159: 245-248, 1995.

42. Levanon D and Groner Y: Structure and regulated expression of mammalian RUNX genes. Oncogene 23: 4211-4219, 2004.

43. Bangsow C, Rubins N, Glusman G, Bernstein Y, Negreanu V, Goldenberg D, Lotem J, Ben-Asher E, Lancet D, Levanon D and Groner Y: The RUNX3 gene-sequence, structure and regulated expression. Gene 279: 221-232, 2001.

44. Marshall LJ, Moore AC, Ohki M, Kitabayashi I, Patterson D and Ornelles DA: RUNX1 permits E4orf6-directed nuclear localization of the adenovirus E1B-55K protein and associates with centers of viral DNA and RNA synthesis. J Virol 82: 6395-408, 2008.

45. Stock M and Otto F: Control of RUNX2 isoform expression: The role of promoters and enhancers. J Cell Biochem 95: 506-517, 2005.

46. Miyoshi H, Ohira M, Shimizu K, Mitani K, Hirai H, Imai T, Yokoyama K, Soeda E and Ohki M: Alternative splicing and genomic structure of the AML1 gene involved in acute myeloid leukemia. Nucleic Acids Res 23: 2762-2769, 1995.

47. Kagoshima H, Shigesada K, Satake M, Ito Y, Miyoshi H, Ohki M, Pepling $\mathrm{M}$ and Gergen P: The runt domain identifies a new family of heterometric transcriptional regulators. Trends Genet 9: 338-341, 1993.

48. Nagata T, Gupta V, Sorce D, Kim WY, Sali A, Chait BT, Shigesada K, Ito Y and Werner MH: Immunoglobulin motif DNA recognition and heterodimerization of the PEBP2/CBF Runt domain. Nat Struct Biol 6: 615-619, 1999.

49. Williams AF and Barclay AN: The immunoglobulin superfamily-domains for cell surface recognition. Annu Rev Immunol 6: 381-405, 1988

50. Javed A, Guo B,HiebertS, Choi JY, Green J,Zhao SC, Osborne MA Stifani S, Stein JL, Lian JB, et al: Groucho/TLE/R-esp proteins associate with the nuclear matrix and repress RUNX (CBF(alpha)/AML/PEBP2(alpha)) dependent activation of tissue-specific gene transcription. J Cell Sci 113: 2221-2231, 2000
51. Imai Y, Kurokawa M, Tanaka K, Friedman AD, Ogawa S, Mitani K, Yazaki Y and Hirai H: TLE, the human homolog of groucho, interacts with AML1 and acts as a repressor of AML1-induced transactivation. Biochem Biophys Res Commun 252: 582-589, 1998.

52. Zaidi SK, Javed A, Choi JY, van Wijnen AJ, Stein JL, Lian JB and Stein GS: A specific targeting signal directs Runx2/Cbfa1 to subnuclear domains and contributes to transactivation of the osteocalcin gene. J Cell Sci 114: 3093-3102, 2001.

53. Stein GS, Lian JB, Stein JL, van Wijnen AJ, Choi JY, Pratap J and Zaidi SK: Temporal and spatial parameters of skeletal gene expression: Targeting RUNX factors and their coregulatory proteins to subnuclear domains. Connect Tissue Res 44 (Suppl 1): S149-S153, 2003.

54. Harrington KS, Javed A, Drissi H, McNeil S, Lian JB, Stein JL, Van Wijnen AJ, Wang YL and Stein GS: Transcription factors RUNX1/AML1 and RUNX2/Cbfa1 dynamically associate with stationary subnuclear domains. J Cell Sci 115: 4167-4176, 2002.

55. Kanno T, Takahashi T, Tsujisawa T, Ariyoshi W and Nishihara T: Mechanical stress-mediated Runx2 activation is dependent on Ras/ERK1/2 MAPK signaling in osteoblasts. J Cell Biochem 101: 1266-1277, 2007.

56. Terry A, Kilbey A, Vaillant F, Stewart M, Jenkins A, Cameron E and Neil JC: Conservation and expression of an alternative 3'exon of Runx2 encoding a novel proline-rich C-terminal domain. Gene 336: 115-125, 2004.

57. Tahirov TH, Inoue-Bungo T, Morii H, Fujikawa A, Sasaki M, Kimura K, Shiina M, Sato K, Kumasaka T, Yamamoto M, et al: Structural analyses of DNA recognition by the AML1/Runx-1 Runt domain and its allosteric control by CBFbeta. Cell 104: 755-767, 2001.

58. Pozner A, Goldenberg D, Negreanu V, Le S, Elroy-stein O, Levanon D and Groner Y: Transcription-coupled translation control of AML1/RUNX1 is mediated by Cap-and internal ribosome entry site-dependent mechanisms. Mol Cell Biol 20: 2297-2307, 2000.

59. Xiao ZS, Simpson LG and Quarles LD: IRES-dependent translational control of Cbfa1/Runx2 expression. J Cell Biochem 88: 493-505, 2003

60. Tang X, Sun L, Wang G, Chen B and Luo F: RUNX1: A regulator of NF-kB signaling in pulmonary diseases. Curr Protein Pept Sci 19: 172-178, 2018 .

61. Webber BR, Iacovino M, Choi SH, Tolar J, Kyba M and Blazar BR: DNA methylation of Runx1 regulatory regions correlates with transition from primitive to definitive hematopoietic potential in vitro and in vivo. Blood 122: 2978-2986, 2013.

62. Sood R, Kamikubo Y and Liu P: Role of RUNX1 in hematological malignancies. Blood 129: 2070-2082, 2017.

63. Jonason JH, Xiao G, Zhang M, Xing L and Chen D Post-translational Regulation of Runx2 in Bone and Cartilage. J Dent Res 88: 693-703, 2009.

64. Rojas A, Aguilar R, Henriquez B, Lian JB, Stein JL, Stein GS, van Wijnen AJ, van Zundert B, Allende ML and Montecino M: Epigenetic control of the bone-master Runx2 gene during osteoblast-lineage commitment by the histone demethylase JARID1B/KDM5B. J Biol Chem 290: 28329-28342, 2015

65. O'Riordan M and Grosschedl R: Transcriptional regulation of early B-lymphocyte differentiation. Immunol Rev 175: 94-103, 2000.

66. Leiden JM and Thompson CB: Transcriptional regulation of T-cell genes during T-cell development. Curr Opin Immunol 6: 231-237, 1994.

67. Kurklu B, Whitehead RH, Ong EK, Minamoto T, Fox JG, Mann JR, Judd LM, Giraud AS and Menheniott TR: Lineage-specific RUNX3 hypomethylation marks the preneoplastic immune component of gastric cancer. Oncogene 34: 2856-2866, 2015 .

68. Appel E, Weissmann S, Salzberg Y, Orlovsky K, Negreanu V, Tsoory M, Raanan C,Feldmesser E, Bernstein Y, Wolstein O, et al: An ensemble of regulatory elements controls Runx3 spatiotemporal expression in subsets of dorsal root ganglia proprioceptive neurons. Genes Dev 30: 2607-2622, 2016.

69. Levanon D, Lotem J, Negreanu V, et al: Transcription regulation in development and disease. Life Sci Open Day: 1-3, 2008.

70. Kojo S, Tanaka H, Endo TA, Muroi S, Liu Y, Seo W, Tenno M, Kakugawa K, Naoe Y, Nair K, et al: Priming of lineage-specifying genes by Bcl11b is required for lineage choice in post-selection thymocytes. Nat Commun 8: 702, 2017.

71. Cho JY, Akbarali Y, Zerbini LF, Gu X, Boltax J, Wang Y, Oettgen P, Zhang DE and Libermann TA: Isoforms of the Ets transcription factor NERF/ELF-2 physically interact with AML1 and mediate opposing effects on AML1-mediated transcription of the B cell-specific blk gene. J Biol Chem 279: 19512-19522, 2004 
72. D'Alonzo RC, Selvamurugan N, Karsenty G and Partridge NC: Physical interaction of the activator protein-1 factors c-Fos and c-Jun with Cbfa1 for collagenase-3 promoter activation. J Biol Chem 277: 816-822, 2002.

73. Pelletier N, Champagne N, Stifani S and Yang XJ: MOZ and MORF histone acetyltransferases interact with the Runt-domain transcription factor Runx2. Oncogene 21: 2729-2740, 2002.

74. Levanon D, Glusman G, Bangsow T, Ben-Asher E, Male DA, Avidan N, Bangsow C, Hattori M, Taylor TD, Taudien S, et al: Architecture and anatomy of the genomic locus encoding the human leukemia-associated transcription factor RUNX1/AML1. Gene 262: 23-33, 2001.

75. Aho TL, Sandholm J, Peltola KJ, Ito Y and Koskinen PJ: Pim-1 kinase phosphorylates RUNX family transcription factors and enhances their activity. BMC Cell Biol 7: 21, 2006.

76. Kim HR, Oh BC, Choi JK and Bae SC: Pim-1 kinase phosphorylates and stabilizes RUNX3 and alters its subcellular localization. J Cell Biochem 105: 1048-1058, 2008.

77. Blyth K, Terry A, Mackay N, Vaillant F, Bell M, Cameron ER, Neil JC and Stewart M: Runx2: A novel oncogenic effector revealed by in vivo complementation and retroviral tagging. Oncogene 20: 295-302, 2001.

78. Tanaka T, Kurokawa M, Ueki K, Tanaka K, Imai Y, Mitani K, Okazaki K, Sagata N, Yazaki Y, Shibata Y, et al: The extracellular signal-regulated kinase pathway phosphorylates AML1, an acute myeloid leukemia gene product, and potentially regulates its transactivation ability. Mol Cell Biol 16: 3967-3979, 1996.

79. Imai Y, Kurokawa M, Yamaguchi Y, Izutsu K, Nitta E, Mitani K, Satake M, Noda T, Ito Y and Hirai $\mathrm{H}$ : The corepressor mSin3A regulates phosphorylation-induced activation, intranuclear location, and stability of AML1. Mol Cell Biol 24: 1033-1043, 2004.

80. Wee HJ, Voon DC, Bae SC and Ito Y: PEBP2-beta/CBF-beta dependent phosphorylation of RUNX1 and p300 by HIPK2: Implications for leukemogenesis. Blood 112: 3777-3787, 2008.

81. Aikawa Y, Nguyen LA, Isono K, Takakura N, Tagata Y, Schmitz ML, Koseki H and Kitabayashi I: Roles of HIPK1 and HIPK2 in AML1-and p300-dependent transcription, hematopoiesis and blood vessel formation. EMBO J 25: 3955-3965, 2006.

82. Seo W, Tanaka H, Miyamoto C, Levanon D, Groner Y and Taniuchi I: Roles of VWRPY motif-mediated gene repression by Runx proteins during T-cell development. Immunol Cell Biol 90: 827-830, 2012.

83. Westendorf JJ, Zaidi SK, Cascino JE, Kahler R, van Wijnen AJ, Lian JB, Yoshida M, Stein GS and Li X: Runx2 (Cbfa1, AML-3) interacts with histone deacetylase 6 and represses the p21(CIP1/WAF1) promoter. Mol Cell Biol 22: 7982-7992, 2002.

84. Durst KL and Hiebert SW: Role of RUNX family members in transcriptional repression and gene silencing. Oncogene 23 : 4220-4224, 2004.

85. Kasahara K, Shiina M, Fukuda I, Ogata K and Nakamura H: Molecular mechanisms of cooperative binding of transcription factors Runx1-CBF $\beta$-Ets1 on the TCR $\alpha$ gene enhancer. PLoS One 12: e0172654, 2017.

86. Hassig CA, Fleischer TC, Billin AN, Schreiber SL and Ayer DE: Histone deacetylase activity is required for full transcriptional repression by mSin3A. Cell 89: 341-347, 1997.

87. Gelmetti V, Zhang J, Fanelli M, Minucci S, Pelicci PG and Lazar MA: Aberrant recruitment of the nuclear receptor corepressor-histone deacetylase complex by the acute myeloid leukemia fusion partner ETO. Mol Cell Biol 18: 7185-7191, 1998.

88. Huang G, Shigesada K, Ito K, Wee HJ, Yokomizo T and Ito Y: Dimerization with PEBP2beta protects RUNX1/AML1 from ubiquitin-proteasome-mediated degradation. EMBO J 20 : 723-733, 2001.

89. Zelent A, Greaves M and Enver T: Role of the TEL-AML1 fusion gene in the molecular pathogenesis of childhood acute lymphoblastic leukaemia. Oncogene 23: 4275-4283, 2004.

90. Bakshi R, Hassan MQ, Pratap J, Lian JB, Montecino MA, van Wijnen AJ, Stein JL, Imbalzano AN and Stein GS: The human SWI/SNF complex associates with RUNX1 to control transcription of hematopoietic target genes. J Cell Physiol 225: 569-576, 2010

91. Henriquez B, Hepp M, Merino P, Sepulveda H, van Wijnen AJ, Lian JB, Stein GS, Stein JL and Montecino M: C/EBP $\beta$ binds the P1 promoter of the Runx2 gene and up-regulates Runx2 transcription in osteoblastic cells. J Cell Physiol 226: 3043-3052, 2011.
92.De Bruijn $M$ and Dzierzak E: Runx transcription factors in the development and function of the definitive hematopoietic system. Blood 129: 2061-2069, 2017.

93. Inoue K, Ozaki S, Shiga T, Ito K, Masuda T, Okado N, Iseda T, Kawaguchi S, Ogawa M, Bae SC, et al: Runx3 controls the axonal projection of proprioceptive dorsal root ganglion neurons. Nat Neurosci 5: 946-954, 2002

94. Senzaki K, Ozaki S, Yoshikawa M, Ito Y and Shiga T: Runx3 is required for the specification of TrkC-expressing mechanoreceptive trigeminal ganglion neurons. Mol Cell Neurosci 43: 296-307, 2010

95. Woolf E, Brenner O, Goldenberg D, Levanon D and Groner Y: Runx3 regulates dendritic epidermal T cell development. Dev Biol 303: 703-714, 2007.

96. Kamikubo Y: Genetic compensation of RUNX family transcription factors in leukemia. Cancer Sci 109: 2358-2363, 2018.

97. Ross K, Sedello AK, Todd GP, Paszkowski-Rogacz M, Bird AW, Ding L, Grinenko T, Behrens K, Hubner N, Mann M, et al: Polycomb group ring finger 1 cooperates with Runx1 in regulating differentiation and self-renewal of hematopoietic cells. Blood 119: 4152-4161, 2012

98. Yokomizo T, Ogawa M, Osato M, Kanno T, Yoshida H, Fujimoto T, Fraser S, Nishikawa S, Okada H, Satake M, et al: Requirement of Runx1/AML1/PEBP2alphaB for the generation of haematopoietic cells from endothelial cells. Genes Cells 6: $13-23,2001$

99. Tanaka K, Tanaka T, Ogawa S, Kurokawa M, Mitani K, Yazaki Y and Hirai H: Increased expression of AML1 during retinoic-acid-induced differentiation of U937 cells. Biochem Biophys Res Commun 211: 1023-1030, 1995.

100. Pratap J, Galindo M, Zaidi SK, Vradii D, Bhat BM, Robinson JA, Choi JY, Komori T, Stein JL, Lian JB, et al: Cell growth regulatory role of Runx2 during proliferative expansion of preosteoblasts. Cancer Res 63: 5357-5362, 2003

101. Galindo M, Pratap J, Young DW, Hovhannisyan H, Im HJ, Choi JY, Lian JB, Stein JL, Stein GS and van Wijnen AJ: The bone-specific expression of Runx2 oscillates during the cell cycle to support a $\mathrm{G}$ 1-related Antiproliferative function in osteoblasts. J Biol Chem 280: 20274-20285, 2005

102. Stein GS, Lian JB, Van Wijnen AJ, Stein JL, Montecino M, Javed A, Zaidi SK, Young DW, Choi JY and Pockwinse SM: Runx2 control of organization, assembly and activity of the regulatory machinery for skeletal gene expression. Oncogene 23: 4315-4329, 2004.

103. Krege JH, Hodgin JB, Couse JF, Enmark E, Warner M, Mahler JF, Sar M, Korach KS, Gustafsson JA and Smithies O: Generation and reproductive phenotypes of mice lacking estrogen receptor beta. Proc Natl Acad Sci USA 95: 15677-15682, 1998.

104. Ehrhardt GR, Hijikata A, Kitamura H, Ohara O, Wang JY and Cooper MD: Discriminating gene expression profiles of memory B cell subpopulations. J Exp Med 205: 1807-1817, 2008.

105. Vaillant F, Blyth K, Andrew L, Neil JC and Cameron ER Enforced expression of Runx 2 perturbs $\mathrm{T}$ cell development at a stage coincident with beta-selection. J Immunol 169: 2866-2874, 2002.

106. Taniuchi I, Osato M, Egawa T, Sunshine MJ, Bae SC, Komori T, Ito $\mathrm{Y}$ and Littman DR: Differential requirements for Runx proteins in CD4 repression and epigenetic silencing during T lymphocyte development. Cell 111: 621-633, 2002.

107. Bauer O, Sharir A, Kimura A, Hantisteanu S, Takeda S and Groner Y: Loss of osteoblast Runx3 produces severe congenital osteopenia. Mol Cell Biol 35: 1097-109, 2015.

108. Wotton S, Terry A, Kilbey A, Jenkins A, Herzyk P and Neil JC UKPMC funders group gene array analysis reveals a common Runx transcriptional program controlling cell adhesion and survival. Oncogene 27: 5856-5866, 2008.

109. Zaidi SK, Pande S, Pratap J, Gaur T, Grigoriu S, Ali SA, Stein JL, Lian JB, van Wijnen AJ and Stein GS: Runx2 deficiency and defective subnuclear targeting bypass senescence to promote immortalization and tumorigenic potential. Proc Natl Acad Sci USA 104: 19861-19866, 2007.

110. Ghali O, Chauveau C, Hardouin P, Broux O and Devedjian JC: TNF-alpha's effects on proliferation and apoptosis in human mesenchymal stem cells depend on RUNX2 expression. J Bone Miner Res 25: 1616-1626, 2010.

111. Scheitz CJ, Lee TS, McDermitt DJ and Tumbar T: Defining a tissue stem cell-driven Runx1/Stat3 signalling axis in epithelial cancer. EMBO J 31: 4124-4139, 2012.

112. Speck NA and Gilliland DG: Core-binding factors in haematopoiesis and leukaemia. Nat Rev Cancer 2: 502-513, 2002. 
113. Look AT: Oncogenic transcription factors in the human acute leukemias. Science 278: 1059-1064, 1997.

114. Regha K, Assi SA, Tsoulaki O, Gilmour J, Lacaud G and Bonifer C: Developmental-stage-dependent transcriptional response to leukaemic oncogene expression. Nat Commun 6: $7203,2015$.

115. Golub TR, Barker GF, Bohlander SK, Hiebert SW, Ward DC Bray-Ward P, Morgan E, Raimondi SC, Rowley JD and Gilliland DG: Fusion of the TEL gene on 12p13 to the AML1 gene on 21q22 in acute lymphoblastic leukemia. Proc Natl Acad Sci USA 92: 4917-4921, 1995.

116. Nucifora G and Rowley JD: AML1 and the 8;21 and 3;21 translocations in acute and chronic myeloid leukemia. Blood 86: 1-14, 1995

117. Mitani K, Ogawa S, Tanaka T, Miyoshi H, Kurokawa M, Mano H Yazaki Y, Ohki M and Hirai H: Generation of the AML1-EVI-1 fusion gene in the $\mathrm{t}(3 ; 21)(\mathrm{q} 26 ; \mathrm{q} 22)$ causes blastic crisis in chronic myelocytic leukemia. EMBO J 13: 504-510, 1994.

118. Krygier A, Szmajda D, Żebrowska M, Jeleń A and Balcerczak E: Expression levels of the runt-related transcription factor 1 and 3 genes in the development of acute myeloid leukemia. Oncol Lett 15: 6733-6738, 2018.

119. Wotton S, Stewart M, Blyth K, Vaillant F, Kilbey A, Neil JC and Cameron ER: Proviral insertion indicates a dominant oncogenic role for Runx1/AML-1 in T-cell lymphoma. Cancer Res 62: 7181-7185, 2002.

120. Osato M, Asou N, Abdalla E, Hoshino K, Yamasaki H, Okubo T, Suzushima H, Takatsuki K, Kanno T, Shigesada K and Ito Y: Biallelic and heterozygous point mutations in the runt domain of the AML1/PEBP2alphaB gene associated with myeloblastic leukemias. Blood 93: 1817-1824, 1999.

121. Song WJ, Sullivan MG, Legare RD, Hutchings S, Tan X, Kufrin D, Ratajczak J, Resende IC, Haworth C, Hock R, et al: Haploinsufficiency of CBFA2 causes familial thrombocytopenia with propensity to develop acute myelogenous leukaemia. Nat Genet 23: 166-175, 1999.

122. Fonatsch C: The role of chromosome 21 in hematology and oncology. Genes Chromosomes Cancer 49: 497-508, 2010.

123. Banerji S, Cibulskis K, Rangel-Escareno C, Brown KK, Carter SL, Frederick AM, Lawrence MS, Sivachenko AY, Sougnez C, Zou L, et al: Sequence analysis of mutations and translocations across breast cancer subtypes. Nature 486 405-409, 2012.

124. Ellis MJ, Ding L, Shen D, Luo J, Suman VJ, Wallis JW, Van Tine BA, Hoog J, Goiffon RJ, Goldstein TC, et al: Whole-genome analysis informs breast cancer response to aromatase inhibition. Nature 486: 353-360, 2012.

125. Morita K, Suzuki K, Maeda S, Matsuo A, Mitsuda Y, Tokushige C, Kashiwazaki G, Taniguchi J, Maeda R, Noura M, et al: Genetic regulation of the RUNX transcription factor family has antitumor effects. J Clin Invest 127: 2815-2828, 2017.

126. Illendula A, Gilmour J, Grembecka J, Tirumala VSS, Boulton A, Kuntimaddi A, Schmidt C, Wang L, Pulikkan JA, Zong H, et al: Small molecule inhibitor of CBF $\beta$-RUNX binding for RUNX transcription factor driven cancers. EBioMedicine 8: 117-131, 2016

127. Pelassa I, Corà D, Cesano F, Monje FJ, Montarolo PG and Fiumara F: Association of polyalanine and polyglutamine coiled coils mediates expansion disease-related protein aggregation and dysfunction. Hum Mol Genet 23: 3402-3420, 2014.

128. Stewart M, Terry A, Hu M, O'Hara M, Blyth K, Baxter E, Cameron E, Onions DE and Neil JC: Proviral insertions induce the expression of bone-specific isoforms of PEBP2alphaA (CBFA1): Evidence for a new myc collaborating oncogene. Proc Natl Acad Sci USA 94: 8646-8651, 1997.

129. Martin JW, Zielenska M, Stein GS, Van Wijnen AJ and Squire JA: The role of RUNX2 in osteosarcoma oncogenesis. Sarcoma 2011: 282745, 2011.

130. Li N, Luo D, Hu X, Luo W, Lei G, Wang Q, Zhu T, Gu J, Lu Y and Zheng Q: RUNX2 and Osteosarcoma. Anticancer Agents Med Chem 15: 881-887, 2015

131. Pratap J, Lian JB, Javed A, Barnes GL, van Wijnen AJ, Stein JL and Stein GS: Regulatory roles of Runx2 in metastatic tumor and cancer cell interactions with bone. Cancer Metastasis Rev 25: 589-600, 2006.

132. Rucci N and Teti A: Osteomimicry: How tumor cells try to deceive the bone. Front Biosci (Schol Ed) 2: 907-915, 2010.

133. Niu DF, Kondo T, Nakazawa T, Oishi N, Kawasaki T, Mochizuki K, Yamane T and Katoh R: Transcription factor Runx 2 is a regulator of epithelial-mesenchymal transition and invasion in thyroid carcinomas. Lab Invest 92: 1181-1190, 2012.
134.Lim M, Zhong C, Yang S, Bell AM, Cohen MB and Roy-Burman P: Runx2 regulates survivin expression in prostate cancer cells. Lab Invest 90: 222-233, 2010.

135. Pratap J, Javed A, Languino LR, van Wijnen AJ, Stein JL, Stein GS and Lian JB: The Runx2 osteogenic transcription factor regulates matrix metalloproteinase 9 in bone metastatic cancer cells and controls cell invasion. Mol Cell Biol 25: 8581-8591, 2005.

136. Onodera Y, Miki Y, Suzuki T, Takagi K, Akahira J, Sakyu T, Watanabe M, Inoue S, Ishida T, Ohuchi N and Sasano H: Runx2 in human breast carcinoma: Its potential roles in cancer progression. Cancer Sci 101: 2670-2675, 2010.

137. Underwood KF, D'Souza DR, Mochin-Peters M, Pierce AD, Kommineni S, Choe M, Bennett J, Gnatt A, Habtemariam B, MacKerell AD Jr and Passaniti A: Regulation of RUNX2 transcription factor-DNA interactions and cell proliferation by vitamin D3 (cholecalciferol) prohormone activity. J Bone Miner Res 27: 913-925, 2012.

138. Kim MS, Gernapudi R, Choi EY, Lapidus RG and Passaniti A: Characterization of CADD522, a small molecule that inhibits RUNX2-DNA binding and exhibits antitumor activity. Oncotarget 8: 70916-70940, 2017.

139. Tandon M, Gokul K, Ali SA, Chen Z, Lian J, Stein GS and Pratap J: Runx2 mediates epigenetic silencing of the bone morphogenetic protein-3B (BMP-3B/GDF10) in lung cancer cells. Mol Cancer 11: 27, 2012

140. Lotem J, Levanon D, Negreanu V, Bauer O, Hantisteanu S, Dicken J and Groner Y: Runx3 at the interface of immunity, inflammation and cancer. Biochim Biophys Acta 1855: 131-143, 2015.

141. Ito K, Liu Q, Salto-Tellez M, Yano T, Tada K, Ida H, Huang C, Shah N, Inoue M, Rajnakova A, et al: RUNX3, a novel tumor suppressor, is frequently inactivated in gastric cancer by protein mislocalization. Cancer Res 65: 7743-7750, 2005.

142. Goh YM, Cinghu S, Hong ET, Lee YS, Kim JH, Jang JW, Li YH, Chi XZ, Lee KS, Wee H, et al: Src kinase phosphorylates RUNX3 at tyrosine residues and localizes the protein in the cytoplasm. J Biol Chem 285: 10122-10129, 2010.

143. Lau QC, Raja E, Salto-Tellez M, Liu Q, Ito K, Inoue M, Putti TC, Loh M, Ko TK, Huang C, et al: RUNX3 is frequently inactivated by dual mechanisms of protein mislocalization and promoter hypermethylation in breast cancer. Cancer Res 66: 6512-6520, 2006

144. Chen LF: Tumor suppressor function of RUNX3 in breast cancer. J Cell Biochem 113: 1470-1477, 2012

145. Li QL, Ito K, Sakakura C, Fukamachi H, Inoue KI, Chi XZ, Lee KY, Nomura S, Lee CW, Han SB, et al: Causal relationship between the loss of RUNX3 expression and gastric cancer. Cell 109: 113-124, 2002

146. Fujii S, Ito K, Ito Y and Ochiai A: Enhancer of zeste homologue 2 (EZH2) down-regulates RUNX3 by increasing histone H3 methylation. J Biol Chem 283: 17324-17332, 2008.

147. Tsang YH Lamb A and Chen LF: New insights into the inactivation of gastric tumor suppressor RUNX3: The role of $H$. pylori infection. J Cell Biochem 112: 381-386, 2011.

148. Katayama Y, Takahashi M and Kuwayama H: Helicobacter pylori causes runx3 gene methylation and its loss of expression in gastric epithelial cells, which is mediated by nitric oxide produced by macrophages. Biochem Biophys Res Commun 388 496-500, 2009.

149. Yong WP and National University Hospital, Singapore: The effect of preoperative docetaxel, cisplatin and capecitabine on serum RUNX3 hypermethylation status in patients with gastric and lower oesophagus adenocarcinoma. Clin Trials: $1,2017$.

150. Hor YT, Voon DC, Koo JK, Wang H, Lau WM, Ashktorab H, Chan SL and Ito Y: A role for RUNX3 in inflammation-induced expression of IL23A in gastric epithelial cells. Cell Rep 8: 50-58, 2014.

151. National Institutes of Health: GDC data portal: TCGA-HNSC project. US Dep Heal Hum ServlNatl Institutes Heal: 1, 2018.

152. Bae SC, Kolinjivadi AM and Ito Y: Functional relationship between p53 and RUNX proteins. J Mol Cell Biol: Dec 11, 2018 (Epub ahead of print). doi: 10.1093/jmcb/mjy076.

153. Lee JW, van Wijnen A and Bae SC: RUNX3 and p53: How two tumor suppressors cooperate against oncogenic ras? Adv Exp Med Biol 962: 321-332, 2017

154. Saha A and Robertson ES: Epstein-barr virus-associated B-cell lymphomas: Pathogenesis and clinical outcomes. Clin Cancer Res 17: 3056-3063, 2011 
155. Gunnell A, Webb HM, Wood CD, McClellan MJ, Wichaidit B, Kempkes B, Jenner RG, Osborne C, Farrell PJ and West MJ: RUNX super-enhancer control through the Notch pathway by Epstein-Barr virus transcription factors regulates B cell growth Nucleic Acids Res 44: 4636-4650, 2016.

156. Spender LC, Cornish GH, Sullivan A and Farrell PJ: Expression of transcription factor AML-2 (RUNX3, CBF(alpha)-3) Is Induced by Epstein-Barr Virus EBNA-2 and correlates with the B-cell activation phenotype. J Virol 76: 4919-4927, 2002.

157. Levanon D, Bernstein Y, Negreanu V, Bone KR, Pozner A, Eilam R, Lotem J, Brenner O and Groner Y: Absence of Runx3 expression in normal gastrointestinal epithelium calls into question its tumour suppressor function. EMBO Mol Med 3: 593-604, 2011.

158. Lotem J, Levanon D, Negreanu V and Groner Y: The false paradigm of RUNX3 function as tumor suppressor in gastric cancer. J Cancer Ther 4: 16-25, 2013.

159. Levanon D, Negreanu V, Lotem J, Bone KR, Brenner O, Leshkowitz D and Groner Y: Transcription Factor Runx3 regulates interleukin-15-dependent natural killer cell activation. Mol Cell Biol 34: 1158-1169, 2014

160. Whittle MC, Izeradjene K, Rani PG, Feng L, Carlson MA, DelGiorno KE, Wood LD, Goggins M, Hruban RH, Chang AE, et al: RUNX3 controls a metastatic switch in pancreatic ductal adenocarcinoma. Cell 161: 1345-1360, 2015.

161. Whittle MC and Hingorani SR: RUNX3 defines disease behavior in pancreatic ductal adenocarcinoma. Mol Cell Oncol 3: e1076588, 2015 .

162. Jian Z, Cheng T,Zhang Z, Raulefs S, Shi K, Steiger K, Maeritz N, Kleigrewe K, Hofmann T, Benitz S, et al: Glycemic variability promotes both local invasion and metastatic colonization by pancreatic ductal adenocarcinoma. Cell Mol Gastroenterol Hepatol 6: 429-449, 2018.

163. Lotem J, Levanon D, Negreanu V, Bauer O, Hantisteanu S, Dicken $J$ and Groner Y: Runx3 in immunity, inflammation and cancer. Adv Exp Med Biol 962: 369-393, 2017.

164. Berger AH, Knudson AG and Pandolfi PP: A continuum model for tumour suppression. Nature 476: 163-169, 2011

165. Tsunematsu T, Kudo Y, Iizuka S, Ogawa I, Fujita T, Kurihara H, Abiko Y and Takata T: RUNX3 has an oncogenic role in head and neck cancer. PLoS One 4: e5892, 2009.

166. Manandhar S and Lee YM: Emerging role of RUNX3 in the regulation of tumor microenvironment. BMB Rep 51: 174-181, 2018

167. Pattabiraman DR and Weinberg RA: Tackling the cancer stem cells-what challenges do they pose? Nat Rev Drug Discov 13 497-512, 2014

168. Gopal S, Saraswati S, Sanyal M, Bulbule A, Ramdasi A, Kumar D, Behera R, Ahmed M, Chakraborty G, Kumar V, et al Therapeutic targeting of osteopontin in breast cancer cells. In: Breast cancer-current and alternative therapeutic modalities. InTech: 23-36, 2011.

169. Osorio KM, Lilja KC and Tumbar T: Runx1 modulates adult hair follicle stem cell emergence and maintenance from distinct embryonic skin compartments. J Cell Biol 193: 235-250, 2011.

170. Fortini ME: Notch Signaling: The core pathway and its posttranslational regulation. Dev Cell 16: 633-647, 2009.

171. Yuan X, Wu H, Han N, Xu H, Chu Q, Yu S, Chen Y and Wu K: Notch signaling and EMT in non-small cell lung cancer: Biological significance and therapeutic application. J Hematol Oncol 7: 87, 2014

172. Thouverey $\mathrm{C}$ and Caverzasio J: Focus on the p38 MAPK signaling pathway in bone development and maintenance. Bonekey Rep 4: 711, 2015.

173. Franceschi RT, Xiao G, Jiang D, Gopalakrishnan R, Yang S and Reith E: Multiple signaling pathways converge on the Cbfa1/Runx2 transcription factor to regulate osteoblast differentiation. Connect Tissue Res 44 (Suppl 1): S109-S116, 2003.

174. Nikitovic D, Kavasi RM, Berdiaki A, Papachristou DJ Tsiaoussis J, Spandidos DA, Tsatsakis AM and Tzanakakis GN: Parathyroid hormone/parathyroid hormone-related peptide regulate osteosarcoma cell functions: Focus on the extracellular matrix (Review). Oncol Rep 36: 1787-1792, 2016.

175. Cohen-Solal KA, Boregowda RK and Lasfar A: RUNX2 and the PI3K/AKT axis reciprocal activation as a driving force for tumor progression. Mol Cancer 14: 137, 2015.

176. Petcherski AG and Kimble J: Mastermind is a putative activator for Notch. Curr Biol 10: R471-R473, 2000.

177. Nakagawa M, Ichikawa M, Kumano K, Goyama S, Kawazu M Asai T, Ogawa S, Kurokawa M and Chiba S: AML1/Runx rescues Notch1-null mutation-induced deficiency of para-aortic splanchnopleural hematopoiesis. Blood 108: 3329-3334, 2006.
178. Burns CE, Traver D, Mayhall E, Shepard JL and Zon LI: Hematopoietic stem cell fate is established by the Notch-Runx pathway. Genes Dev 19: 2331-2342, 2005.

179. Meier-Stiegen F, Schwanbeck R, Bernoth K, Martini S, Hieronymus T, Ruau D, Zenke M and Just U: Activated Notch1 target genes during embryonic cell differentiation depend on the cellular context and include lineage determinants and inhibitors. PLoS One 5: e11481, 2010.

180. Ann EJ, Kim HY, Choi YH, Kim MY, Mo JS, Jung J, Yoon JH, Kim SM, Moon JS, Seo MS, et al: Inhibition of Notch1 signaling by Runx2 during osteoblast differentiation. J Bone Miner Res 26: 317-330, 2011.

181. Shen $\mathrm{Q}$ and Christakos S: The vitamin D receptor, Runx2, and the notch signaling pathway cooperate in the transcriptional regulation of osteopontin. J Biol Chem 280: 40589-40598, 2005

182. Fu YX, Chang AC, Fournier M, Chang L, Niessen K and Karsan A: RUNX3 maintains the mesenchymal phenotype after termination of the notch signal. J Biol Chem 286: 11803-11813, 2011

183. Cadigan KM and Peifer M: Wnt signaling from development to disease: Insights from model systems. Cold Spring Harb Perspect Biol 1: a002881, 2009.

184. Chen F, Liu X, Bai J, Pei D and Zheng J: The emerging role of RUNX3 in cancer metastasis (Review). Oncol Rep 35: 1227-1236, 2016.

185. Medina MA, Ugarte GD, Vargas MF, Avila ME, Necuñir D, Elorza AA, Gutiérrez SE and De Ferrari GV: Alternative RUNX1 promoter regulation by $\mathrm{Wnt} / \beta$-catenin signaling in leukemia cells and human hematopoietic progenitors. J Cell Physiol 231: 1460-1467, 2016.

186. Moore A, Tahinci E, Lee E and Hiebert S: RUNX1-ETO stimulates wnt signaling by inhibiting the function of ETO family member proteins. Blood 104: 2554, 2004.

187. Dong YF, Soung do Y, Schwarz EM, O'Keefe RJ and Drissi H: Wnt induction of chondrocyte hypertrophy through the Runx2 transcription factor. J Cell Physiol 208: 77-86, 2006.

188. Gaur T, Lengner CJ, Hovhannisyan H, Bhat RA, Bodine PV, Komm BS, Javed A, van Wijnen AJ, Stein JL, Stein GS and Lian JB: Canonical WNT signaling promotes osteogenesis by directly stimulating Runx2 gene expression. J Biol Chem 280: 33132-33140, 2005

189. Attisano L and Labbé E: TGFbeta and Wnt pathway cross-talk. Cancer Metastasis Rev 23: 53-61, 2004

190. Ju X, Ishikawa TO, Naka K, Ito K, Ito Y and Oshima M: Context-dependent activation of Wnt signaling by tumor suppressor RUNX3 in gastric cancer cells. Cancer Sci 105: $418-424,2014$

191. Chimge NO and Frenkel B: The RUNX family in breast cancer: Relationships with estrogen signaling. Oncogene 32: 2121-2130, 2013.

192. Mitsuda Y, Morita K, Kashiwazaki G, Taniguchi J, Bando T, Obara M, Hirata M, Kataoka TR, Muto M, Kaneda Y, et al: RUNX1 positively regulates ErbB2/HER2 signaling pathway through modulating the expression of SOS1 in gastric cancer cells. Sci Rep 8: 6423, 2018.

193. Khalid O, Baniwal SK, Purcell DJ, Leclerc N, Gabet Y, Stallcup MR, Coetzee GA and Frenkel B: Modulation of Runx2 activity by estrogen receptor-alpha: Implications for osteoporosis and breast cancer. Endocrinology 149: 5984-5995, 2008.

194. Chimge NO, Baniwal SK, Little GH, Chen YB, Kahn M, Tripathy D, Borok Z and Frenkel B: Regulation of breast cancer metastasis by Runx 2 and estrogen signaling: The role of SNAI2. Breast Cancer Res 13: R127, 2011

195. Teplyuk NM, Galindo M, Teplyuk VI, Pratap J, Young DW, Lapointe D, Javed A, Stein JL, Lian JB, Stein GS and van Wijnen AJ: Runx2 regulates $G$ protein-coupled signaling pathways to control growth of osteoblast progenitors. J Biol Chem 283: 27585-27597, 2008.

196. Berry NB, Fan M and Nephew KP: Estrogen Receptor-alpha Hinge-Region Lysines 302 and 303 regulate receptor degradation by the proteasome. Mol Endocrinol 22: 1535-1551, 2008.

197. Subramanian K, Jia D, Kapoor-Vazirani P, Powell DR, Collins RE, Sharma D, Peng J, Cheng X and Vertino PM: Regulation of estrogen receptor alpha by the SET7 lysine methyltransferase. Mol Cell 30: 336-347, 2008.

198. Fan M, Park A and Nephew KP: CHIP (Carboxyl Terminus of Hsc70-Interacting Protein) promotes basal and geldanamycin-induced degradation of estrogen receptor-alpha. Mol Endocrinol 19: 2901-2914, 2005 
199. Duong V, Boulle N, Daujat S, Chauvet J, Bonnet S, Neel H and Cavaillès V: Differential regulation of estrogen receptor alpha turnover and transactivation by $\mathrm{Mdm} 2$ and stress-inducing agents. Cancer Res 67: 5513-5521, 2007.

200. Huang B, Qu Z, Ong CW, Tsang YH, Xiao G, Shapiro D, Salto-Tellez M, Ito K, Ito Y and Chen LF: RUNX3 acts as a tumor suppressor in breast cancer by targeting estrogen receptor $\alpha$. Oncogene 31: 527-534, 2012.

201. Yano T, Ito K, Fukamachi H, Chi XZ, Wee HJ, Inoue K, Ida H, Bouillet P, Strasser A, Bae SC and Ito Y: The RUNX3 tumor suppressor upregulates Bim in gastric epithelial cells undergoing transforming growth factor beta-induced apoptosis. Mol Cell Biol 26: 4474-4488, 2006.

202.Krishnan V, Chong YL, Tan TZ, Kulkarni M, Bin Rahmat MB, Tay LS, Sankar H, Jokhun DS, Ganesan A, Chuang LSH, et al: TGF $\beta$ promotes genomic instability after loss of RUNX3. Cancer Res 78: 88-102, 2018.

203. Chi XZ, Yang JO, Lee KY, Ito K, Sakakura C, Li QL, Kim HR, Cha EJ, Lee YH, Kaneda A, et al: RUNX3 suppresses gastric epithelial cell growth by inducing p21(WAF1/Cip1) expression in cooperation with transforming growth factor $\{$ beta\}-activated SMAD. Mol Cell Biol 25: 8097-8107, 2005.

204. Ito K, Lim AC, Salto-Tellez M, Motoda L, Osato M, Chuang LS, Lee CW, Voon DC, Koo JK, Wang H, et al: RUNX3 Attenuates beta-catenin/T cell factors in intestinal tumorigenesis. Cancer Cell 14: 226-237, 2008

205. Tanaka S, Shiraha H, Nakanishi Y, Nishina S, Matsubara M, Horiguchi S, Takaoka N, Iwamuro M, Kataoka J, Kuwaki K, et al: Runt-related transcription factor 3 reverses epithelial-mesenchymal transition in hepatocellular carcinoma. Int J Cancer 131: 2537-2546, 2012.

206. Voon DC, Wang H, Koo JK, Nguyen TA, Hor YT, Chu YS, Ito K, Fukamachi H, Chan SL, Thiery JP and Ito Y: Runx3 protects gastric epithelial cells against epithelial-mesenchymal transition-induced cellular plasticity and tumorigenicity. Stem Cells 30: 2088-2099, 2012.

207. Lee YS, Lee JW, Jang JW, Chi XZ, Kim JH, Li YH, Kim MK, Kim DM, Choi BS, Kim EG, et al: Runx3 Inactivation is a crucial early event in the development of lung adenocarcinoma. Cancer Cell 24: 603-616, 2013.

208. Kilbey A, Blyth K, Wotton S, Terry A, Jenkins A, Bell M, Hanlon L, Cameron ER and Neil JC: Runx2 disruption promotes immortalization and confers resistance to oncogene-induced senescence in primary murine fibroblasts. Cancer Res 67: $11263-11271,2007$
209. Cameron ER, Blyth K, Hanlon L, Kilbey A, Mackay N, Stewart M, Terry A, Vaillant F, Wotton S and Neil JC: The Runx genes as dominant oncogenes. Blood Cells Mol Dis 30: 194-200, 2003.

210. Aronson BD, Fisher AL, Blechman K, Caudy M and Gergen JP: Groucho-dependent and -independent repression activities of Runt domain proteins. Mol Cell Biol 17: 5581-5587, 1997.

211. Fukushima-Nakase Y, Naoe Y, Taniuchi I, Hosoi H, Sugimoto T and Okuda T: Shared and distinct roles mediated through C-terminal subdomains of acute myeloid leukemia/runt-related transcription factor molecules in murine development. Blood 105: 4298-4307, 2005.

212. Goyama S, Yamaguchi Y, Imai Y, Kawazu M, Nakagawa M, Asai T, Kumano K, Mitani K, Ogawa S, Chiba S, et al: The transcriptionally active form of AML1 is required for hematopoietic rescue of the AML1-deficient embryonic para-aortic splanchnopleural (P-Sp) region. Blood 104: 3558-3564, 2004.

213. Javed A, Barnes GL, Jasanya BO, Stein JL, Gerstenfeld L, Lian JB and Stein GS: Runt homology domain transcription factors (Runx, Cbfa, and AML) mediate repression of the bone sialoprotein promoter: Evidence for promoter context-dependent activity of Cbfa proteins. Mol Cell Biol 21: 2891-2905, 2001.

214. Neil JC, Gilroy K, Borlan G, Hay J, Terry A and Kilbey A: The RUNX genes as conditional oncogenes: Insights from retroviral targeting and mouse models. Adv Exp Med Biol 962: 247-264, 2017.

215. Miething C, Grundler R, Mugler C, Brero S, Hoepfl J, Geigl J, Speicher MR, Ottmann O, Peschel C and Duyster J: Retroviral insertional mutagenesis identifies RUNX genes involved in chronic myeloid leukemia disease persistence under imatinib treatment. Proc Natl Acad Sci USA 104: 4594-4599, 2007.

216. Burillo-Sanz S, Vargas MT, Morales-Camacho RM, CaballeroVelázquez T, Sánchez J, García-Lozano JR, Pérez de Soto I, Prats-Martín C, Bernal R and Pérez-Simón JA: RUNX1 amplification in AML with myelodysplasia-related changes and ring 21 chromosomes. Hematol Oncol 35: 894-899, 2017.

217. Ito Y: Oncogenic potential of the RUNX gene family: 'Overview.' Oncogene 23: 4198-4208, 2004.

This work is licensed under a Creative Common Attribution-NonCommercial-NoDerivatives 4.0 International (CC BY-NC-ND 4.0) License. 